\title{
البُعْد اللغوي في مقاصد الشريعة الإسلامية
}

\section{حمادي الموقت}

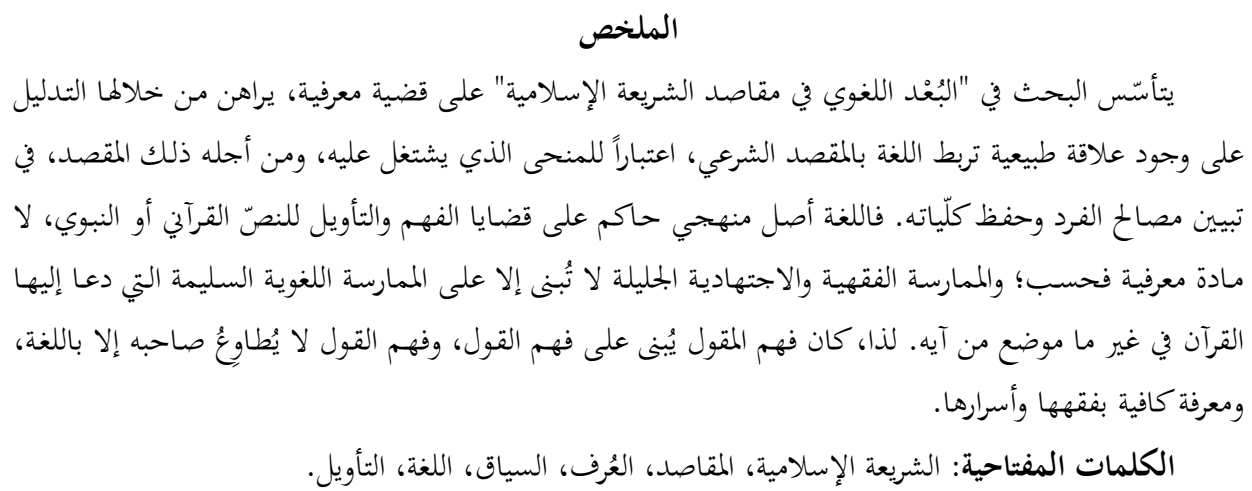

\section{Linguistic Dimension in the Purposes of Islamic law}

Abstract

The study of "linguistic dimension in the purposes of Islamic law" is an epistemological issue through which it seeks to demonstrate the existence of a natural relationship between language and legitimate purpose for which the language is used; i.e., demonstrating the individual's interests and maintaining his or her overall requisites. Language is a methodological foundation for determining human understanding and interpretation of the text of the Qur'an or the Sunnah, and not simply a cognitive matter. The jurisprudential practice is based specifically on the proper linguistic practice required by the Qur'an in many places. The understanding of what is being said, therefore, should be built on understanding of what should be said, and this is dependent on the language and sufficient knowledge of its secrets.

Key words: Islamic legal system, legal intents, societal norm, context, language, interpretation.

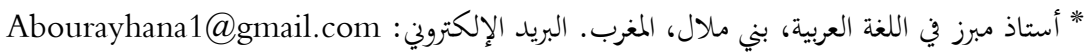

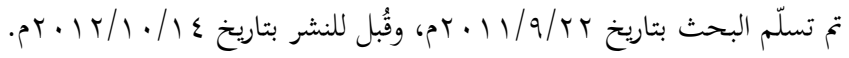


مقدمة:

نعتقد بأنّ القرآن الكريم يهوي معارف يقينية، ولا تُعدّ هذه المعارف مقصداً شرعيّاً

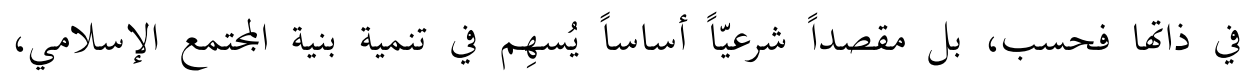
وتقويم سلوكه وفكره وعمله وعلمه بما يتواءم ومنطق الحكمة الإلهية من خَلقِه. غير أنّ المعرفة تتعدّد بتعدّد مصادرها ومرجعياتا وغاياتا، فقد تكون معرفة متخصّصة، وعامّة، ونسبية، إلخا. وإذا اقتصرنا في ورقتنا هذه على استكناه البُعْد اللغوي في مقاصد الشريعة الإسلامية؛ فليس لمحوريته فحسب، بل لكونه -في نظري على الأقلّعمادَ هذه المقاصد التي تضمّنها الخطاب الرباني في آي القرآن، والنبوي في نصوص الحديث؛ إذ بصلاحه صلاح فهمها، وبفساده فساد فهمها. لذلك، كان فهم المقول يُبنى على فهم القول، وفهم القول لا يُطاوِعُ صاحبه إلا باللغة، ومعرفة كافية بفقهها وأسرارها.

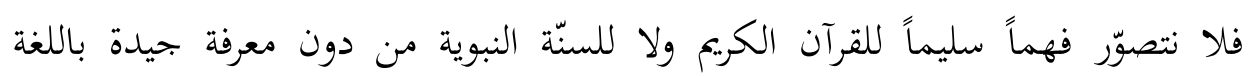
وعلومها؛ من: نحو، وصرف، ومعجم، وبلاغة، ومناطات الدّلالة، ومطلق ومقيّد، وبحمل ومفصّل. تُمّ إنّ غرض الشارع في البَده كان تَبْيِن البُعْد اللغوي وتبيُنه في حياة الفرد الدينية والدنيوية، وشكل تعامله مع القرآن ومقاصده وأحكامه؛ لأنّ من شأن هذا الاهتمام، تحدّي المنكرين، وإثبات عجزهم عن الإتيان بمثله لفظاً ومعنيً، ولو حاولوا لماماً.

وما دامت الكتابات المقاصدية المعروفة' بتُحمِع على أنّ مفهوم المقاصد يُمثّل الغايات المستهدفة والنتائج والفوائد المرجوّة من وضع الشريعة جملة؛ ومن وضع أحكامها تفصيلاً؛

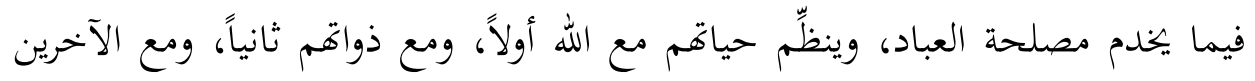

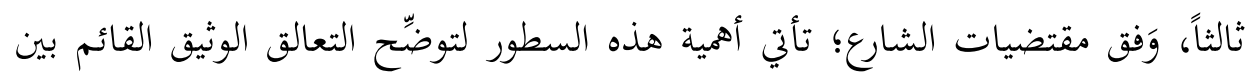

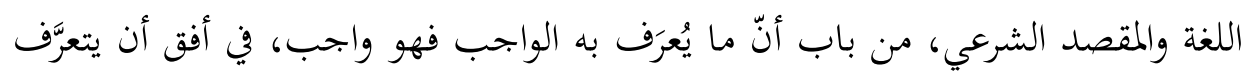

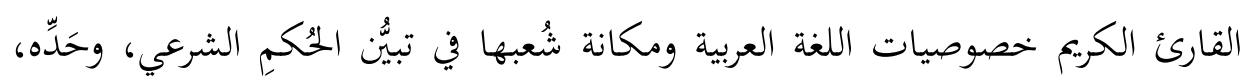
' انظر: "مقاصد الشريعة" للطاهر بن عاشور، و"الفكر المقاصدي" لأمد الريسوني، و"الاجتهاد المقصدي" للخحادمي. 


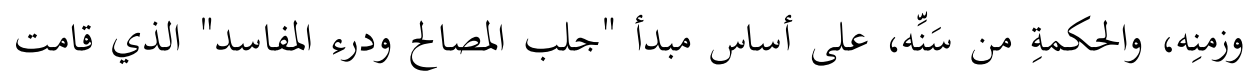

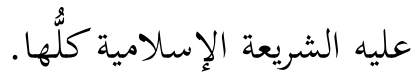

\section{أولاً: حدود العلاقة بين مقاصد الشريعة ونظرية المعرفة}

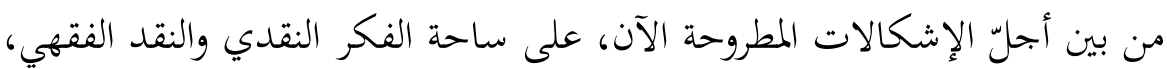

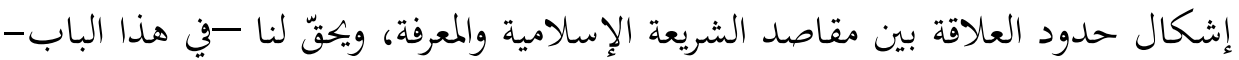

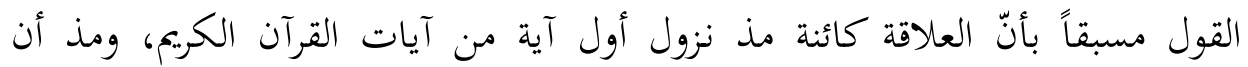

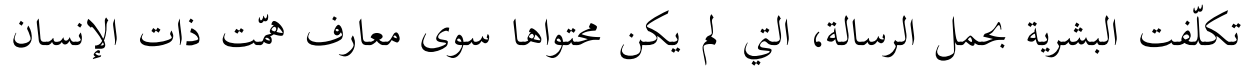

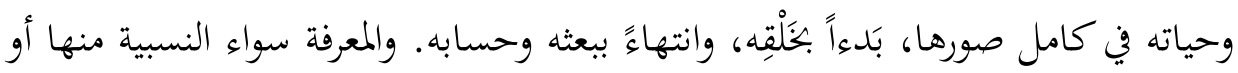

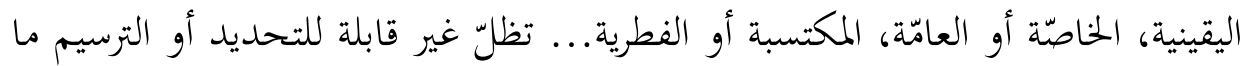

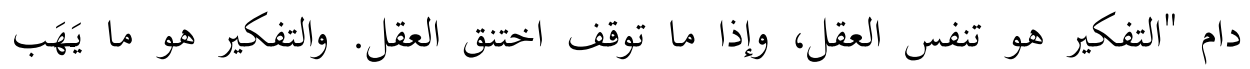
المعلومات معنى، ويجعل للمعرفة مغزى؛ لأن المعرفة تكشف لنا عن مغزاها من المن خلال المال

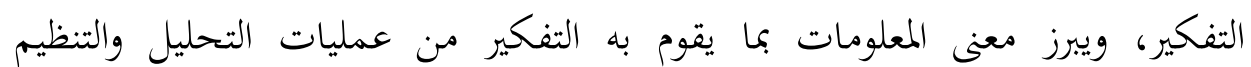

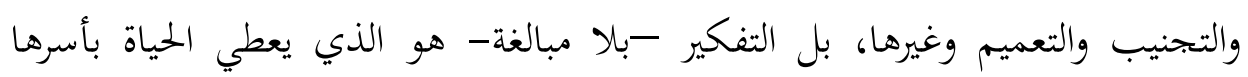
"r"

وفي هذا السياق؛ قد لا أُبالغ إن قُلْتُ: بأنّ المحتمع الإسلامي هو أول البمتمعات

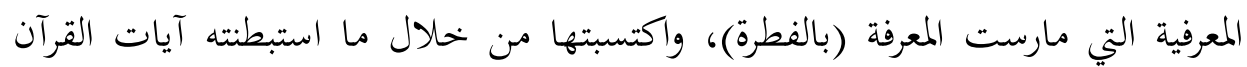

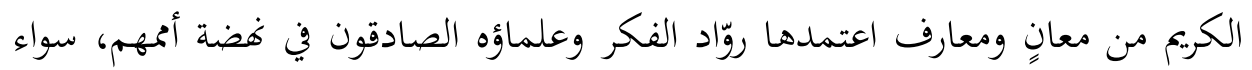

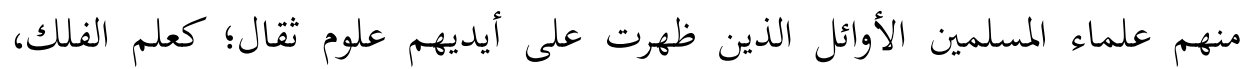

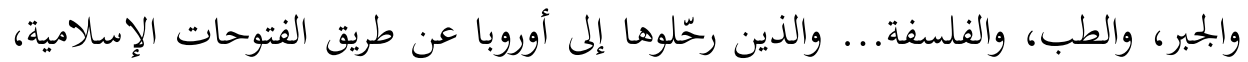

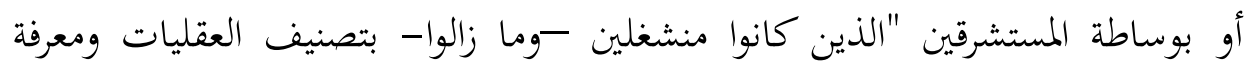

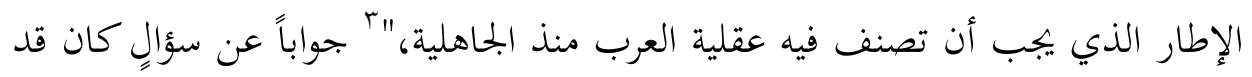

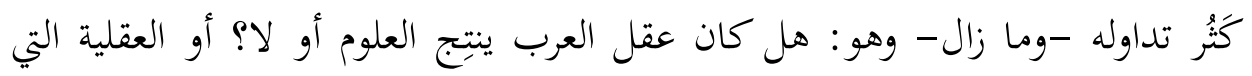

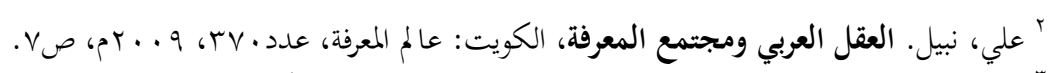

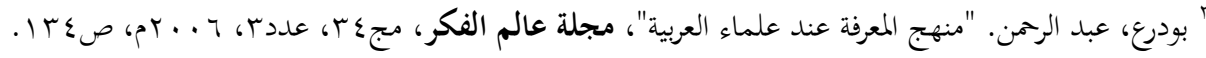


انتشرت بفضل علماء أجادوا فَهْم إسلاميتها المذكورة آنفاً؛ حتى أضحوا هُمْ مصدر

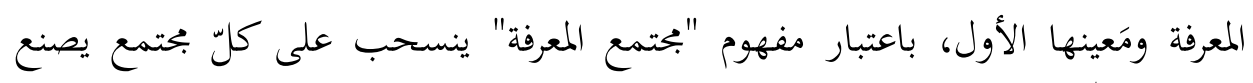

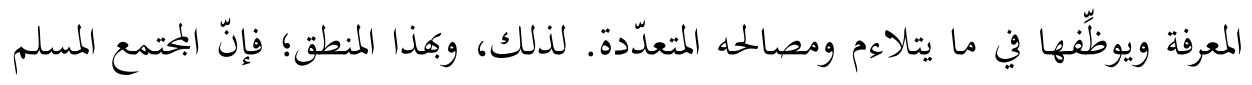

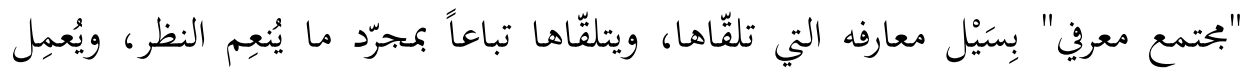

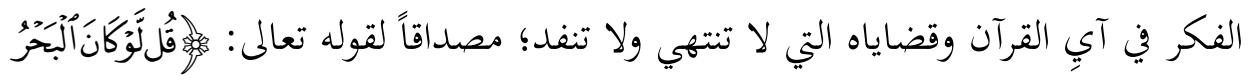

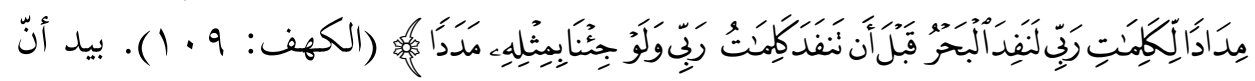

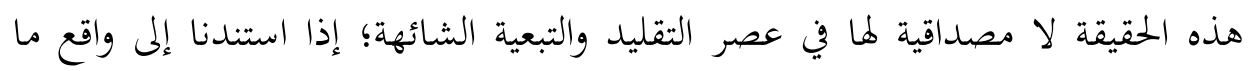

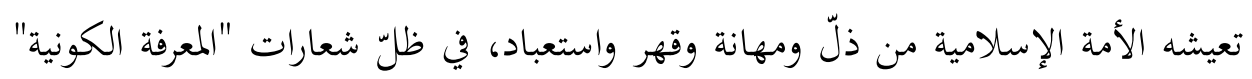

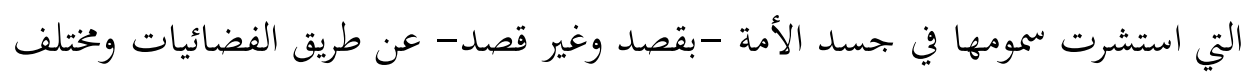

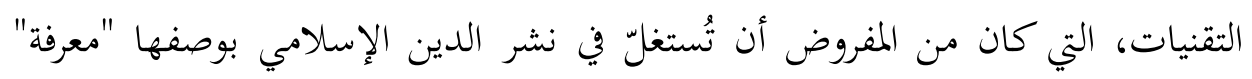
بصيغة الإجمال؛ والدعوة إلى مقاصده الشرعية وِحكمها بوصفها "معرفة" بصيغة التفصيل بالتي هي أحسن؛ ومن دون مواربة، أو ترهيب، أو وعيد. والحقّ يقال؛ إنّ المعرفة بما "تشير إليه من مستويات عليا من التعليم والبحث والتنمية

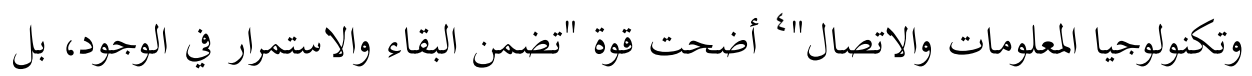
وتحقيق السيطرة والهيمنة في عصر سوف يتميز بالصراع السياسي والاقتصادي والعلمي

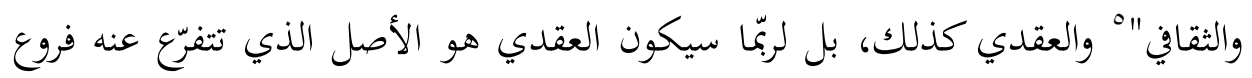

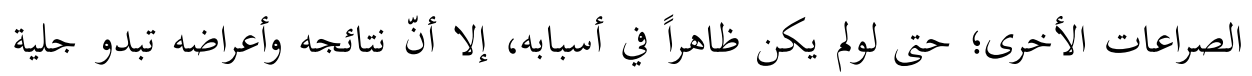

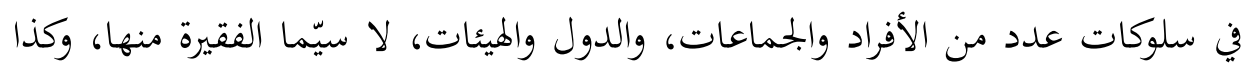

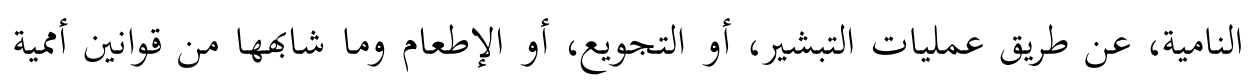
تُلزم "المغلوب" قبل "الغالب" على حدّ وصف علئ ابن خلدون. ومهّ اعتقدنا بأنّ الصراع العقدي هو الأصل، فلأنّه الذي يضبط قواعد التعامل مع

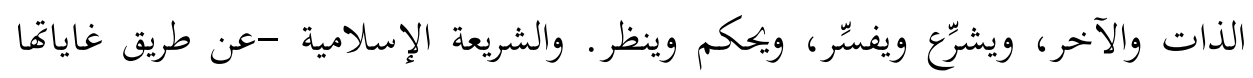

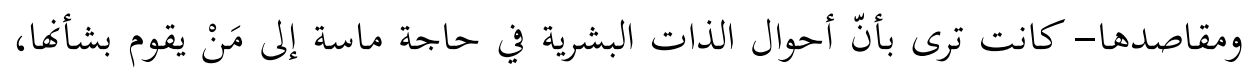

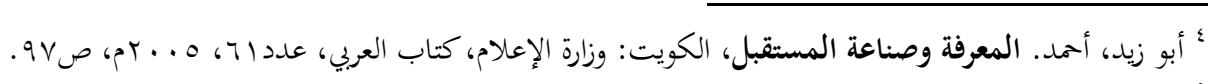

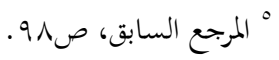




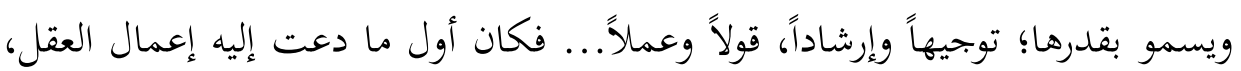

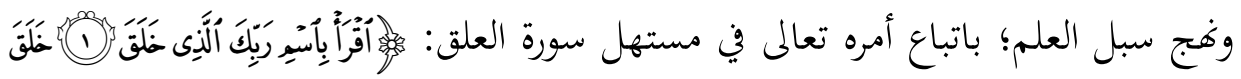

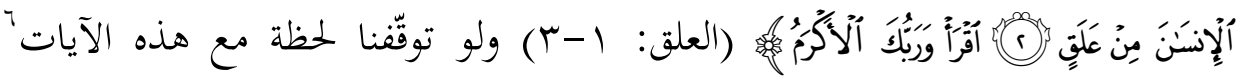

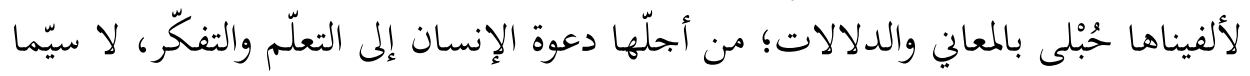

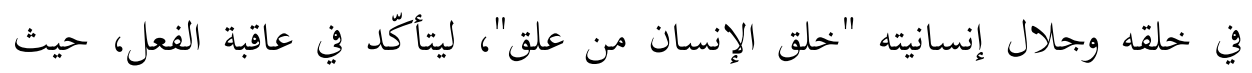

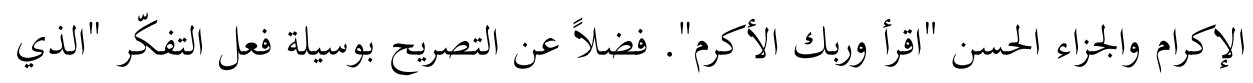

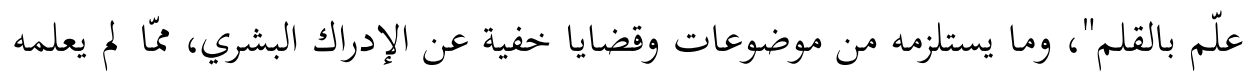

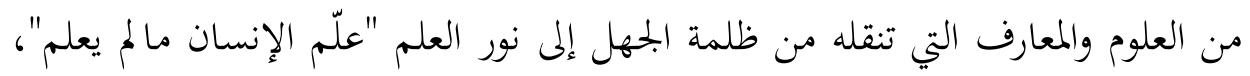

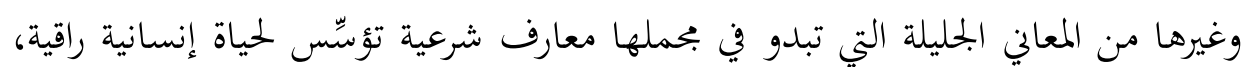

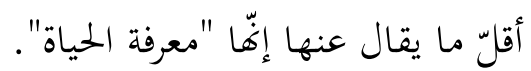

وتأسيساً على ما سلف؛ في علاقة العلم بالمعرفة واللغة، والعقل بالنقل والسماع؛ "أدى النظر في النصوص المروية - وخاصة في العصر العباسي- إلى إثارة إشكال العقل

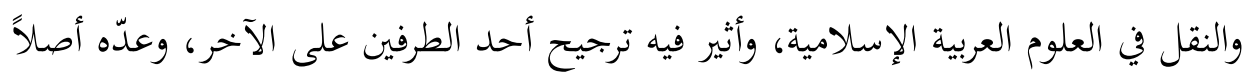

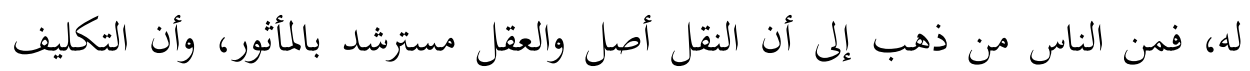
الشرعي سابق للتكليف العقلي، ومنهم من ذهب إلى أن التكليف العقلي شرط في فهم

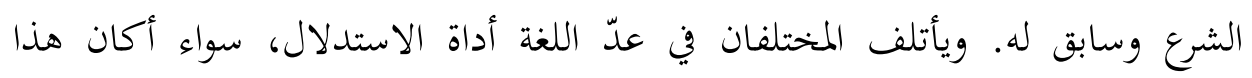

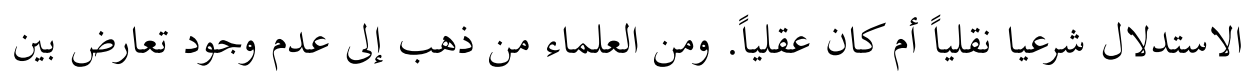

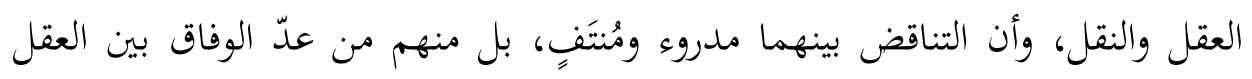

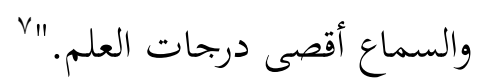

وفي ضوء هذا الوفاق، وانتفاء أسباب الاختلاف بين النقل والعقل؛ تعدّدت العلوم وتداخلت، "حتى إنه ليصعب تمييز علم من آخر، لوحدة المنحى. فإذا كان العلم يفضي

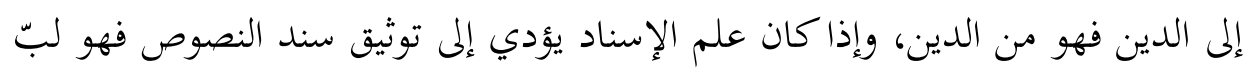

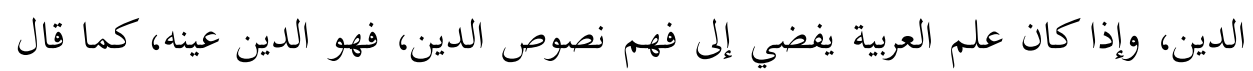

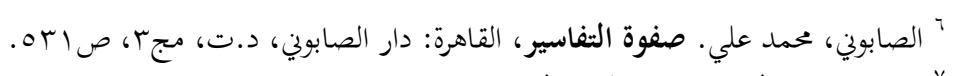

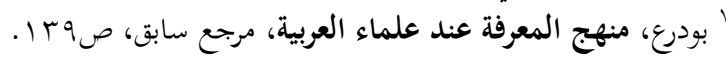


أبو عمرو بن العلاء (واصفاً علم العربية): "علم العربية هو الدين بعينه". فبعلم العربية

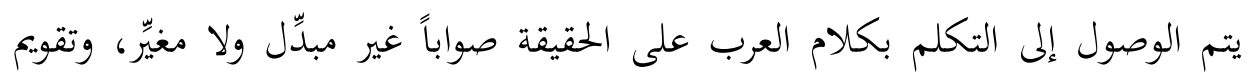

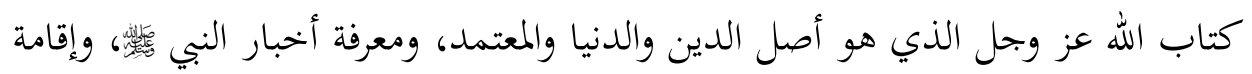

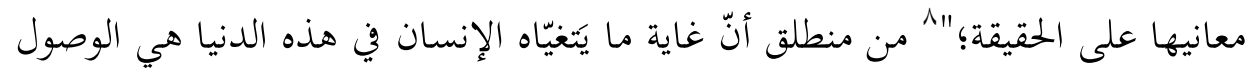

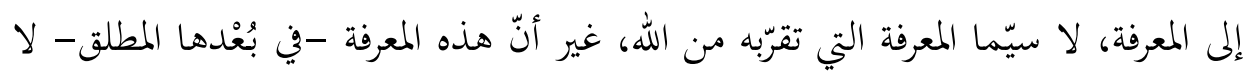

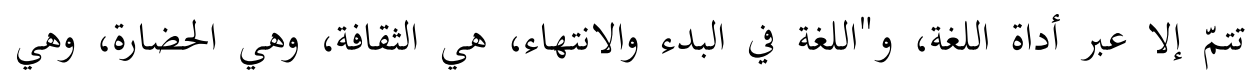

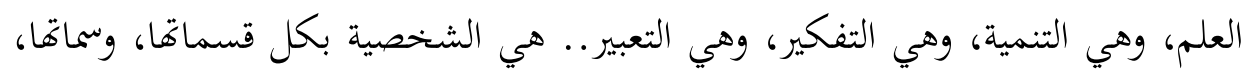

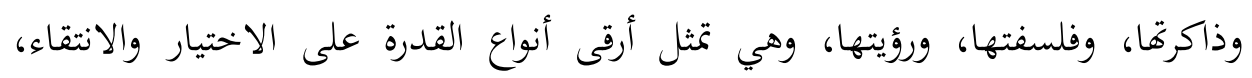

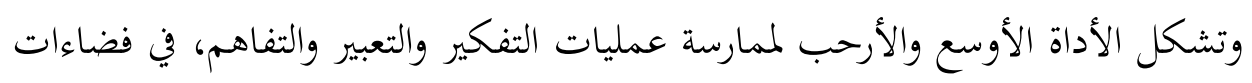

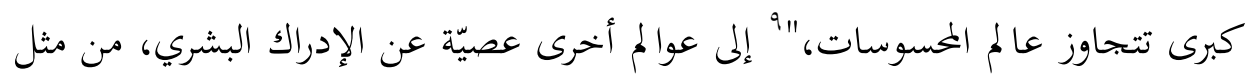
الغايات والمقاصد التي وضعها الله تعالى في أحكامه، ويدبّر بها شؤون العلاقة بينه وبين إلى عردين

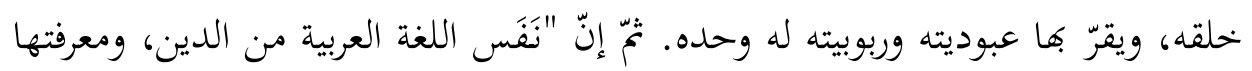

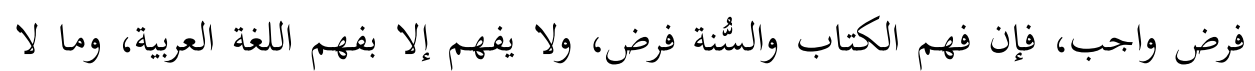

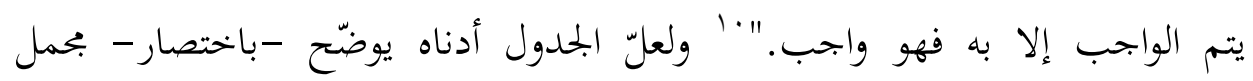

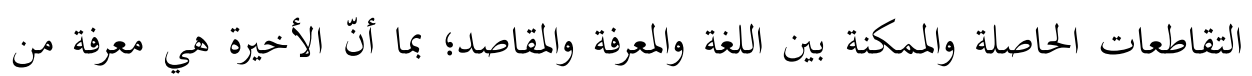
المعارف في ظلّ عالمية الرسالة الإسلامية.

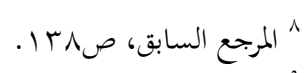
ج بودرع، عبد الرمن وآخرون. اللغة وبناء الذات، قطر : وزارة الأوقاف والشؤون الإسلامية، كتاب الأمة، عدد ا ـ1، 


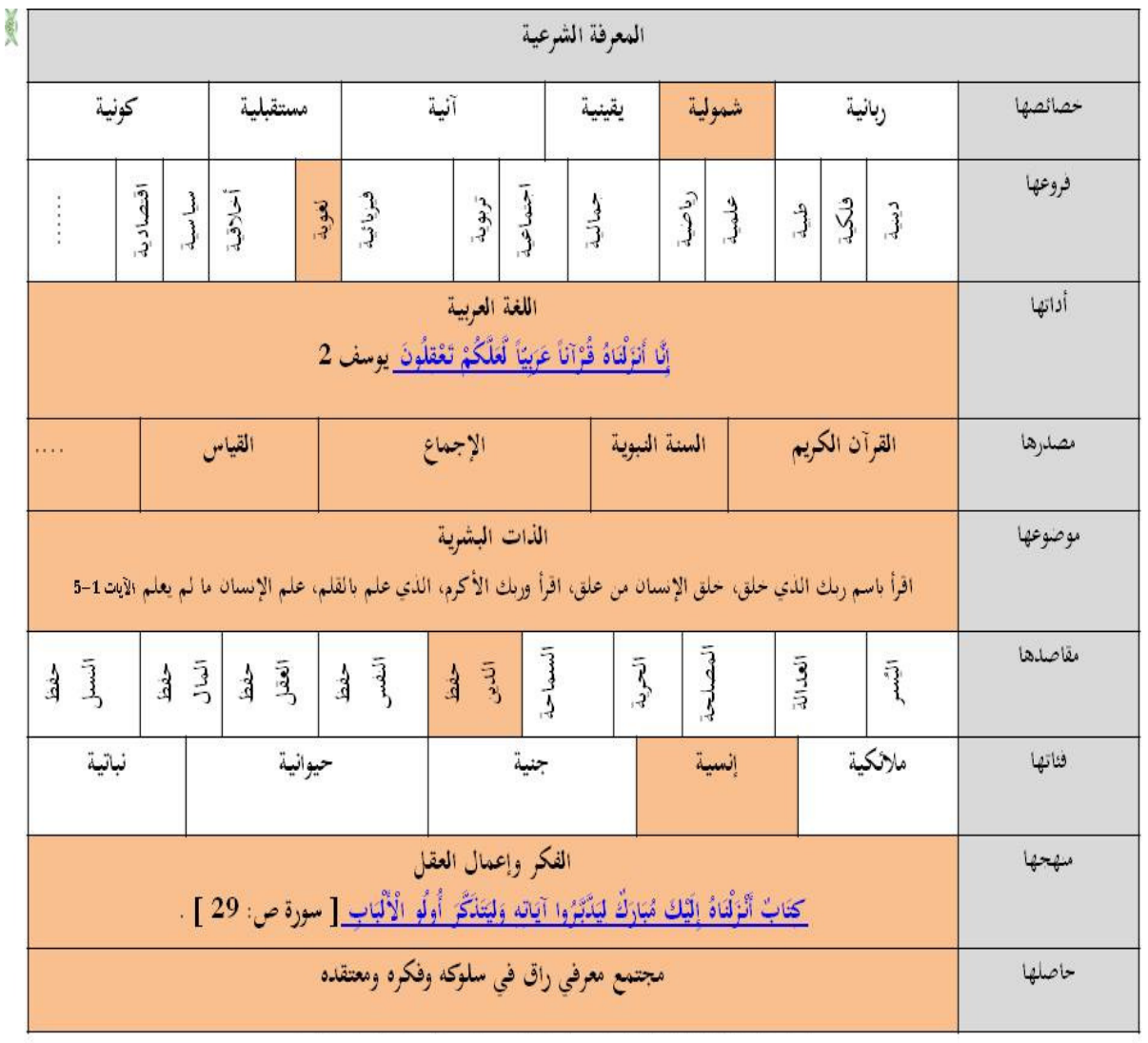

\section{الجدول رقم (1): الرؤية الشاملة لحدود العلاقة بين المعرفة والمقاصد الشرعية}

\section{ثانياً: معرفة اللغة من معرفة الشرع}

لمّ أجمعت الدراسات والبحوث المتخصّصة على أنّ "المعرفة تقال في ما يُتوصل إليه بتفكر وتدبر، وأن العلم قد يقال في ذلك وغيره،"' "كان الغرض المستبطن من هذا الإجماع هو التنصيص على مبدأ "السماع" بوصفه أبلغ منهج يُعتدّ به في تحصيل المعرفة؛

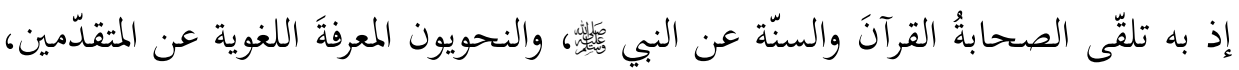




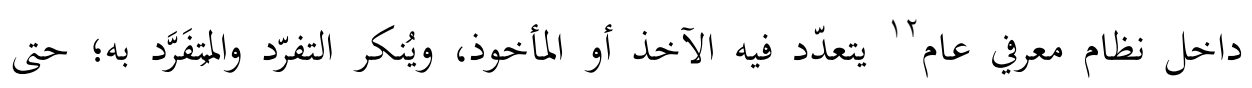
سمعنا بتداخل العلوم، ومنها المسائل الفقهية والنحوية والكامية، بل وإعراب بعضها عمّا سكت عنه المتقدّمون، كما فعل أبو الفتح بن جني -على غرار الكثيرين، با حين حاول

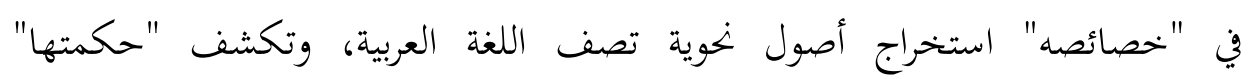
و "صنعتها" على مذهب أصول الكلام والفقه.

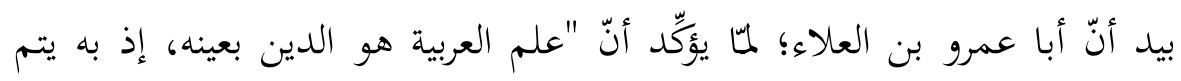

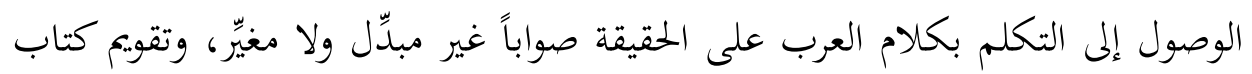

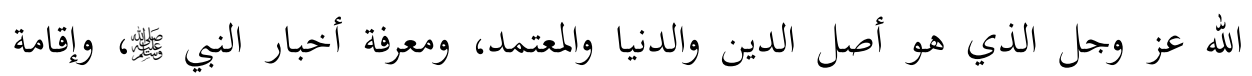

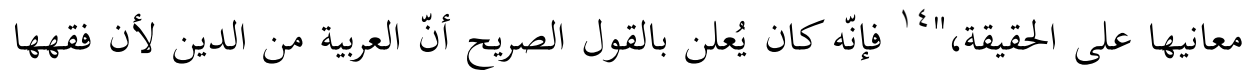

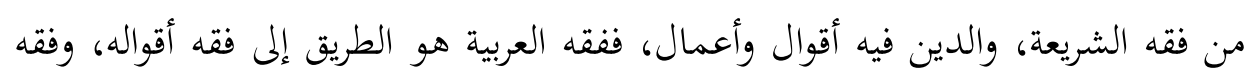

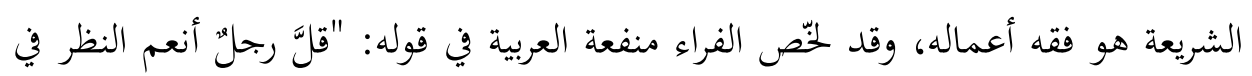

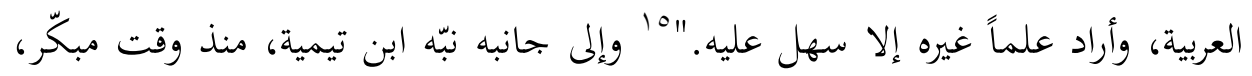

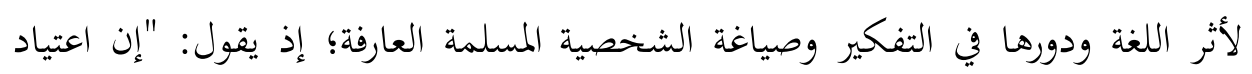

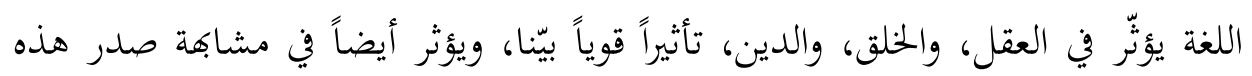

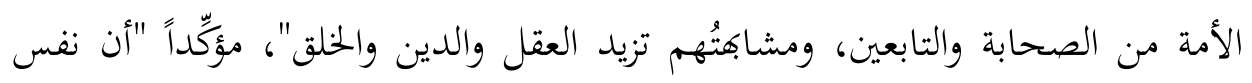

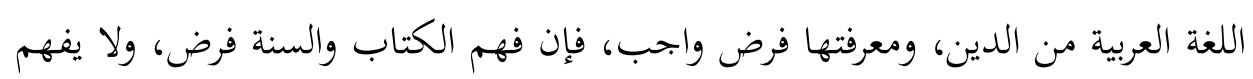

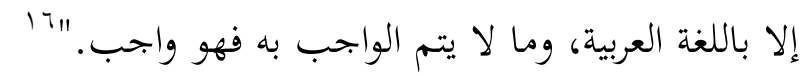

والحقيقة أنّ العربية لم تكن لها هذه المالة في صلتها بالشرع ومقاصده؛ ولم يكن لها تمكّن فيه لولا قوتا، ودقة نظامها، ومرونة قواعدها، وغنى معجمها، وسعة آداجها، وبتذّر

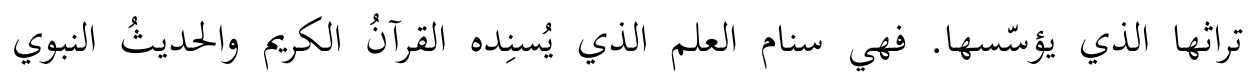

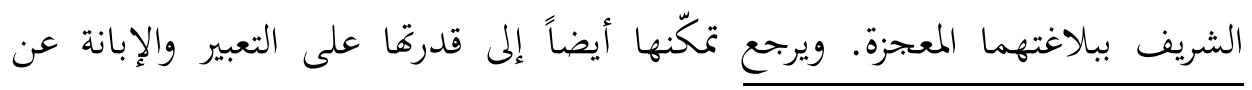

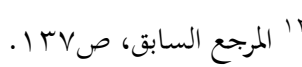

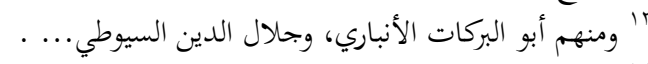

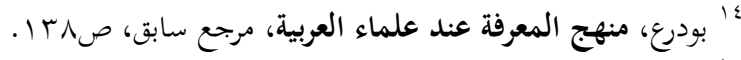

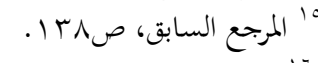
17' بودرع، اللغة وبناء الذات، مرجع سابق، ص • 1. 
مختلف جوانب الفكر والوجدان. فضلاً عن صلتها بالقرآن من باب كوفها لغة مصادر التشريع، ولغة التعبّد. يقول الإمام الشافعي في هذا الصدد: "ولسان العرب أوسع الألسنة

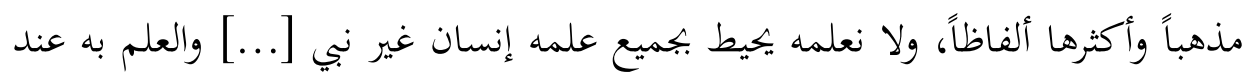

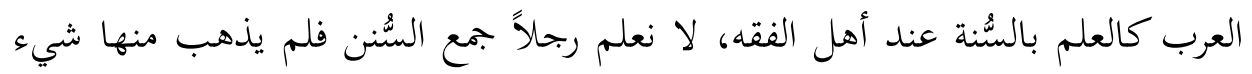

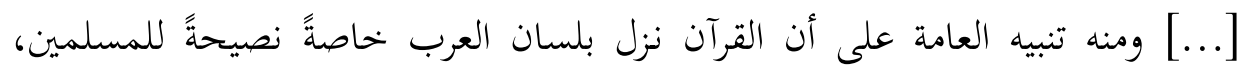

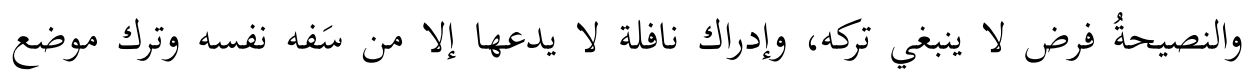

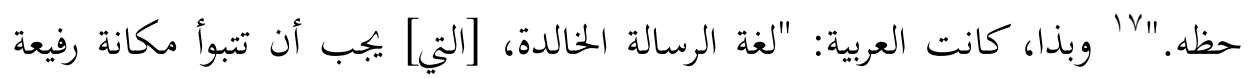

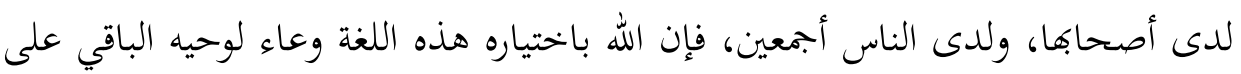
الزمان، قد أعلى قدرها وميزها على سواها،" ويستطرد قائلاً: "والواقع أن اللغة العربية

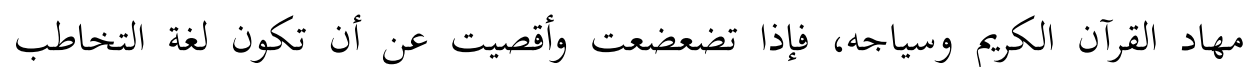

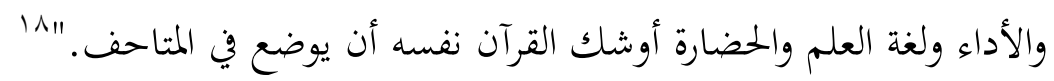
وقد أورد الدكتور أنور الجندي في كتابه "الفصحى لغة القرآن" كلاماً للمستشرق

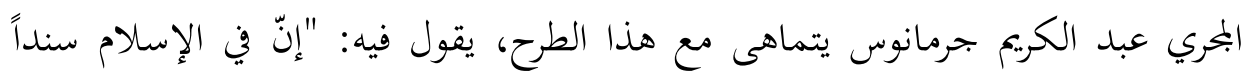

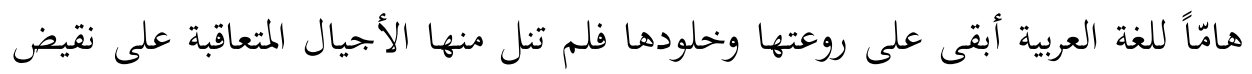

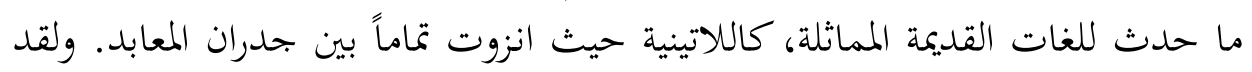

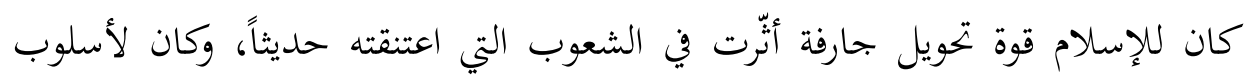

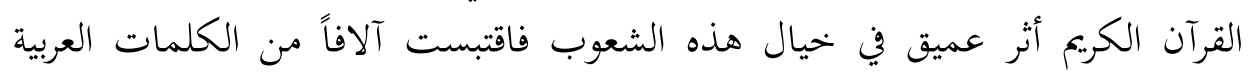

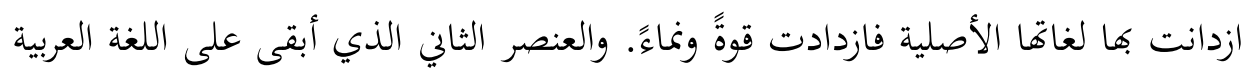

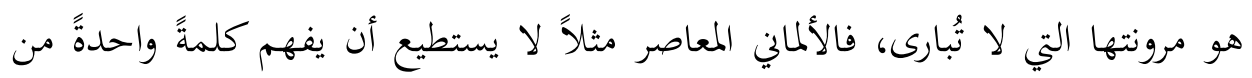

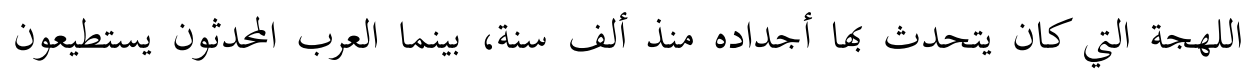

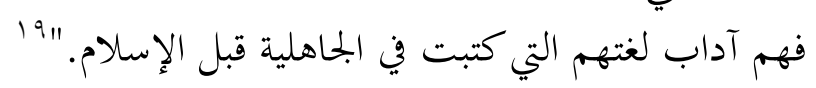

ثمّ في السياق ذاته يُروى عن جوستاف جرونيباوم أنّه قال: "عندما أوحى الله رسالته

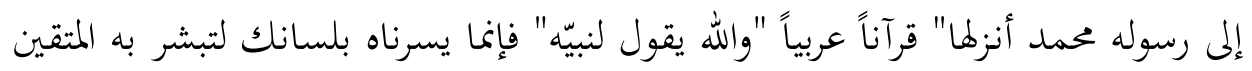

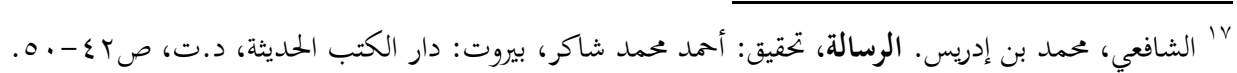

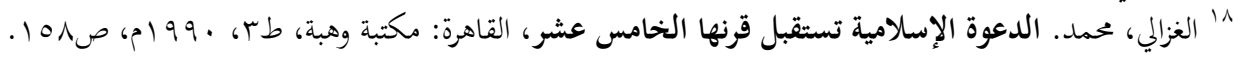

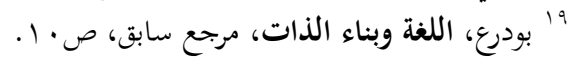


وتنذر به قوماً لدّاً "وما من لغة تستطيع أن تطاول اللغة العربية في شرفها، فهي الوسيلة التي اختيرت لتحمل رسالة الله النهائية، وليست منزلتها الروحية هي وحدها التي تسمو التها

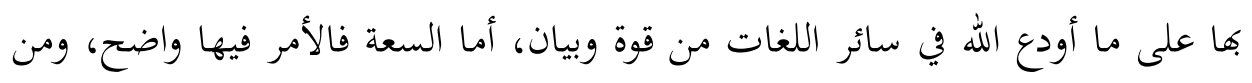

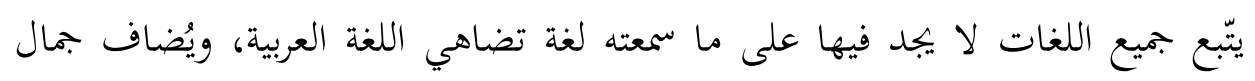
الصوت إلى ثروتا المدهشة في المترادفات. وتزيّن الدقة ووجازة التعبير لغة العرب، وتمتاز

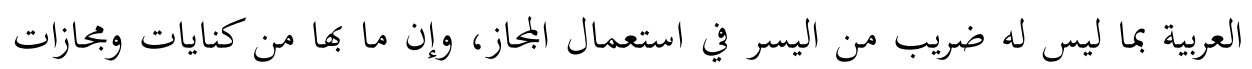
واستعارات ليرفعها كثيراً فوق كل لغة بشرية أخرى، وللغة خصائص جمّة في الأسلوب

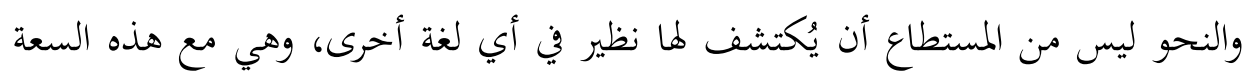

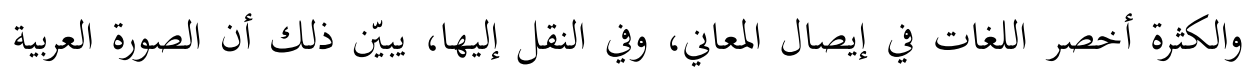

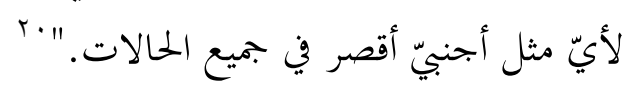

ولعلّ ما سردناه آنفاً من حقائق ساطعة، لا يستطيع جاحد إنكارها، ما دامت تُتْبتِ كينونة العلاقة بين فقه اللغة العربية ومقاصد الشريعة الإسلامية، التي استهوت زمرة

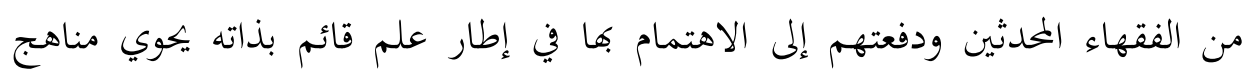
وقواعد وأصولاً، على غرار ما نلفيه في كتابات الدكتور أحمد الريسوني حين يقول متحدّثناً

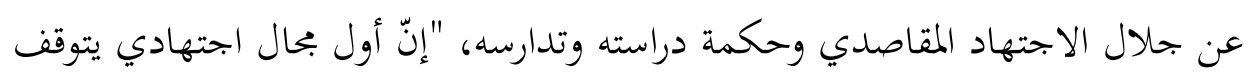
على النظر المقاصدي ويستفيد منه، هو بحال فهم النصوص وتفسيرها سواء كانت قرآنا أم سنة."'r وفهم القرآن الكريم أو السنّة النبوية الشريفة ينبني على البحاهات ومناهج عديدة، حصر بعضها الريسوني -تبعاً لموضوع كتابه- في ثلاثة مناهج، هي: المنهج المقاصدي، والمنهج اللفظي، والمنهج التقويلي (التأويلي).

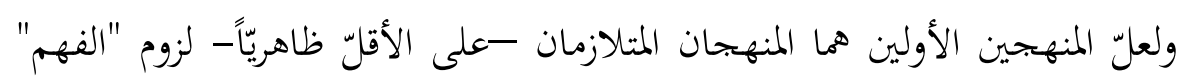

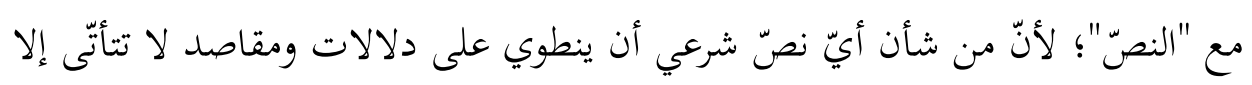

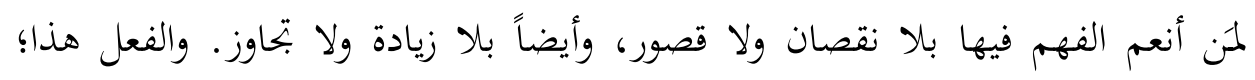

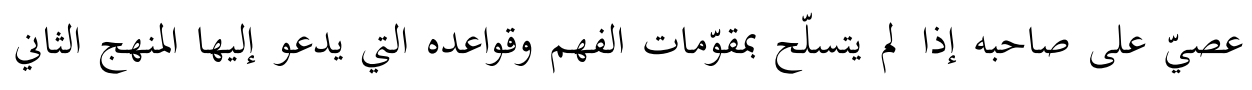

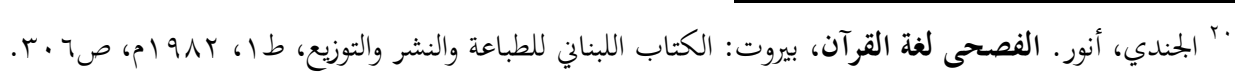

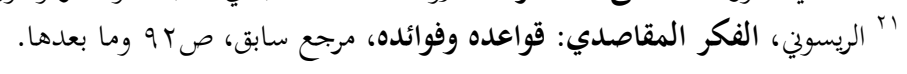




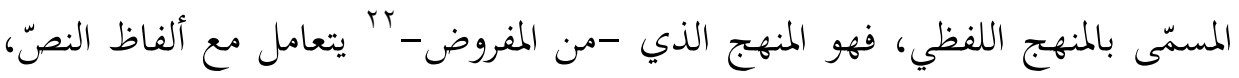

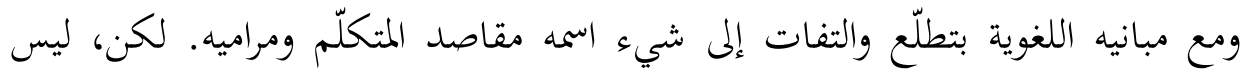

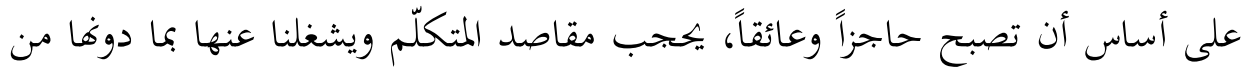

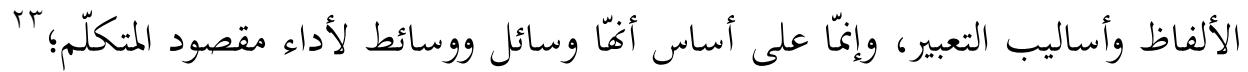

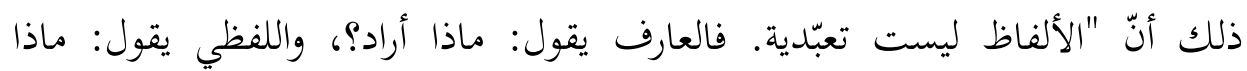
قال؟ دلك

ومن هذا المنطلق؛ فإنّ غايتنا تصحيح المفهوم وقواعد المنهج؛ حتى يتواءم والغاية النبيلة المستخلصة منه. فاللفظ عندنا وسيلة والمعرفة غايته، وبين الوسيلة والغاية فكرٌ جريء يقودها نحو الفهم السليم لمضامين الوحي الرباني، كما يشرح ذلك الجحدول الآتي:

\begin{tabular}{|c|c|c|c|c|c|c|c|c|c|c|c|c|}
\hline \multicolumn{13}{|c|}{ المعرفة اللغوية } \\
\hline \multicolumn{12}{|c|}{ فهم مصادر الشريعة الإسلامية، وتجاوز اللحن والخطأ. } & غرضها \\
\hline \multicolumn{12}{|c|}{ 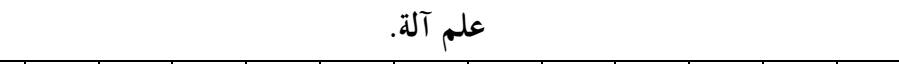 } & صنفها \\
\hline 零 & $\frac{\bar{\pi}}{3}$ & $\frac{\overline{3}}{9}$ & $\begin{array}{l}\overline{7} \\
3 \\
3 \\
\text { : }\end{array}$ & नุ & 勇 & $\bar{s}$ & $\frac{\overline{3}}{y}$ & $\overline{3}$ & $\bar{\xi}$ & $\bar{\alpha}$ & ఫু & 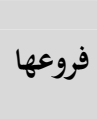 \\
\hline \multicolumn{12}{|c|}{ 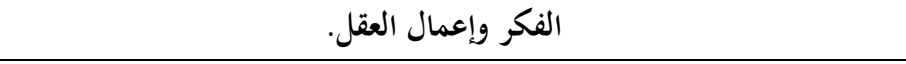 } & منهجها \\
\hline \multicolumn{12}{|c|}{ فهم سليم لمصادر الشريعة الإسلامية بما يتوافق وفهم السلف. } & \\
\hline
\end{tabular}

الجحدول رقم (r): خصوصية المعرفة اللغوية بوصفها فرعاً من فروع المعرفة الشرعية.

غير أنّ محور الإشكال الذي تتمركز عليه المعطيات السالفة، والمعطيات التي ستلي إن شاء الله، هو: كيف ينظر الاجتهاد المقاصدي إلى اللغة؟ أو بصيغة أخرى: هل للغة لتهريه موقع ضمن مباحث علم الاجتهاد المقاصدي؟

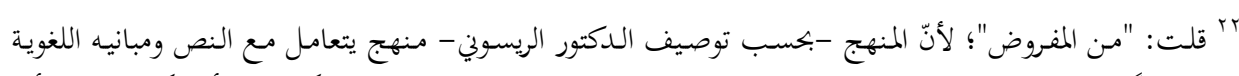

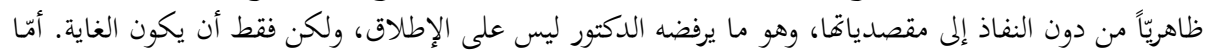

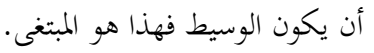

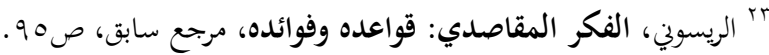

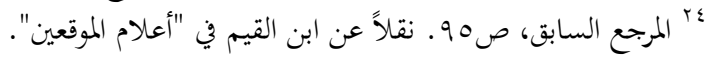




\section{ثالثاً: حاجة المجتهد المقاصدي إلى اللغة}

إنّ أول نخو -من بين خمسة أنخاء- يتصرّف به المختهد الفقيه في الشريعة

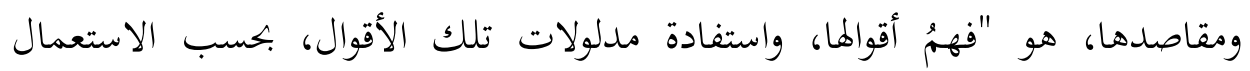

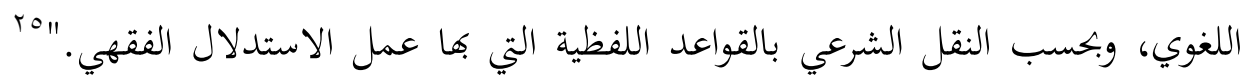

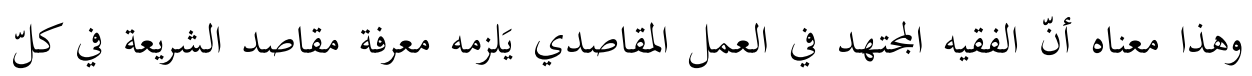

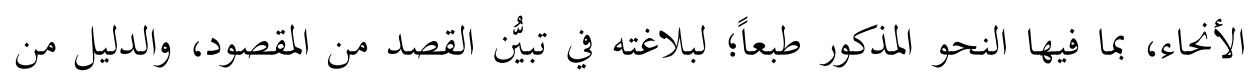
المدلول، ومَنْ يقوم على النصّ مُّن يفتقر إليه.

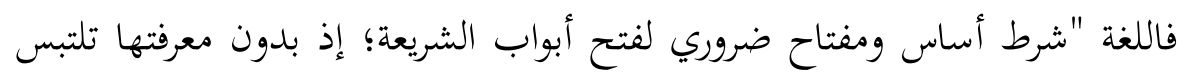

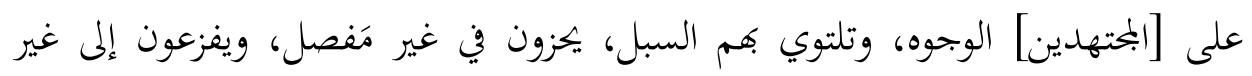

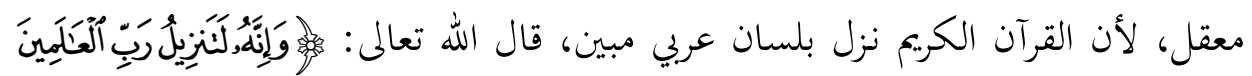

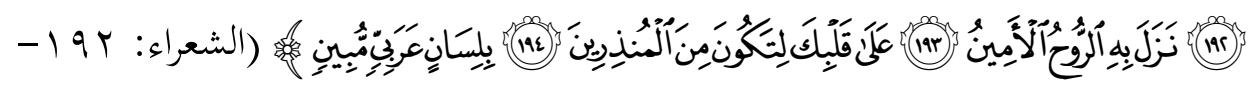
.$(190$

وإذ هو تقرير صريح من ربّ العالمين على عربية القرآن وعربية الشريعة؛ فإنّ هذه

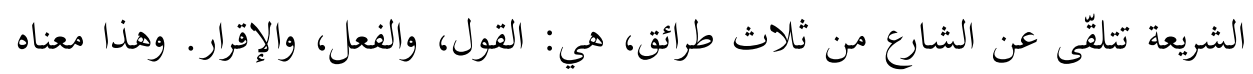

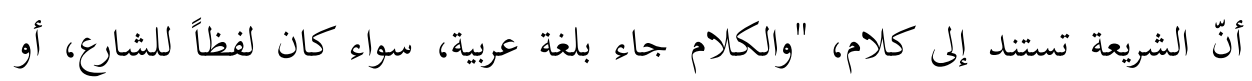

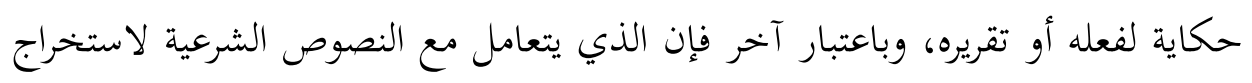

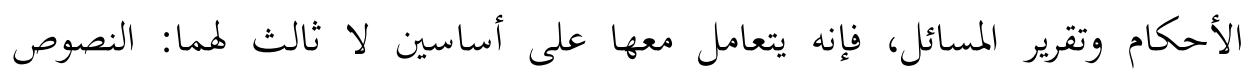
والمقاصد." الاحكام وتبرير

وهذه المكانة التي تحتلّها العربية في خطاب الشرع جعلت السلف الصالح يهتم بها

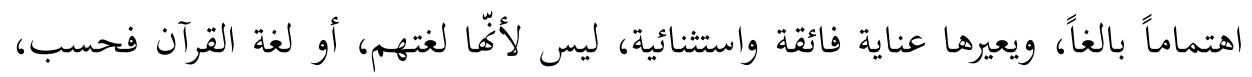
بل لأنّ فهم القرآن وفهم مقاصده من لدن الفقيه والمجتهد، لا يقوم إلا عليها.

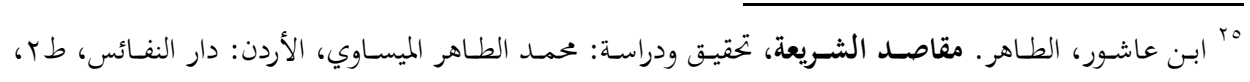

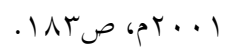

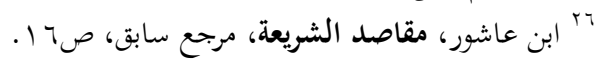




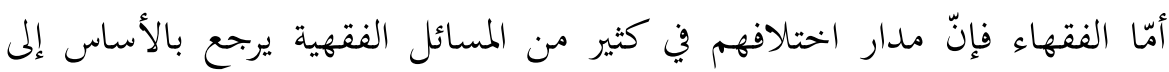

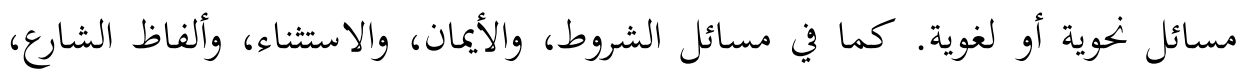

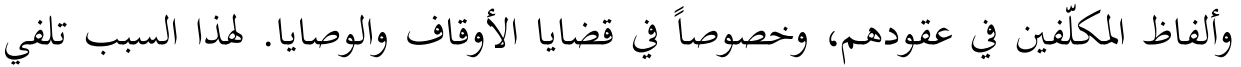

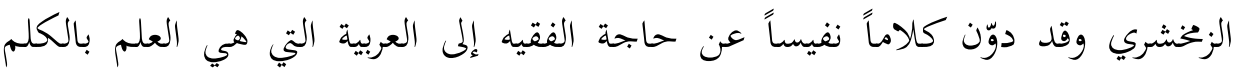

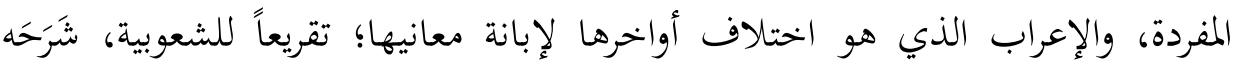

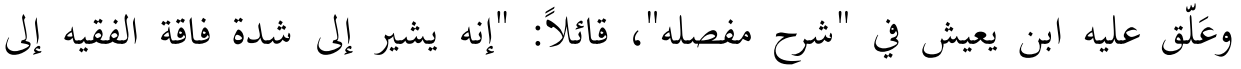

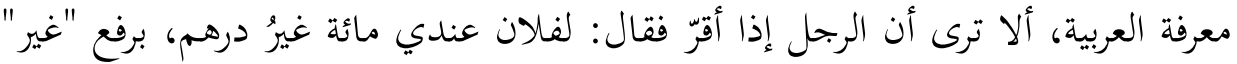

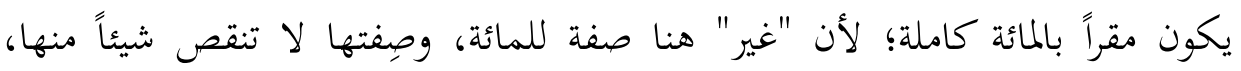

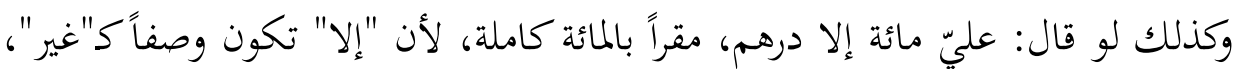

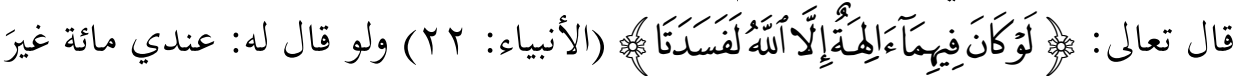
درهم أو إلا درهماً بالنصب لكان فان مقان مقدراً بتسعة وتسعين درهماً، لأنه استثناء والاستثناء

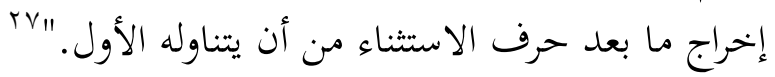

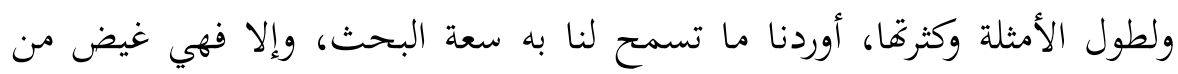

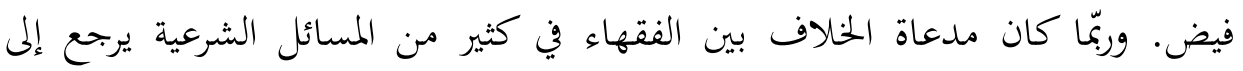

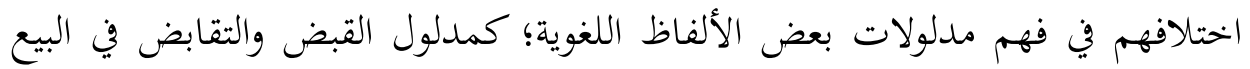

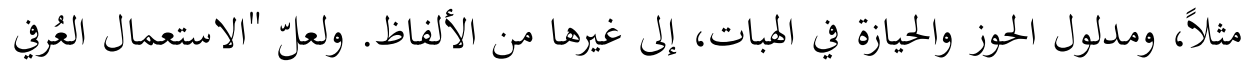

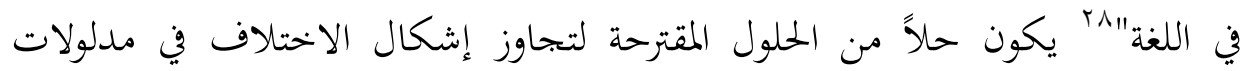

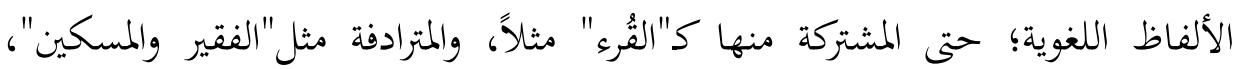

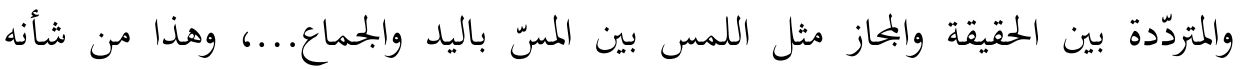

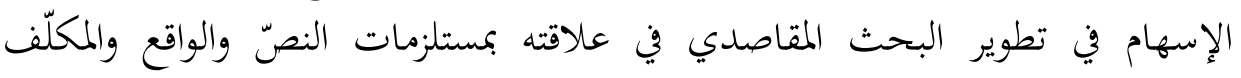
الاجتهادية.

غير أنّ صفوة ما نختتم به هذا المبحث، ما استعرضه ابن بيه من خلاصات عقب

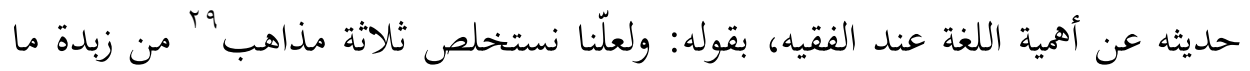

VY ابن بيه، عبد الله بن الشيخ المحفوظ. آمالي الدلالات ومجالي الاختلافات، بيروت: دار بن حزم، المكتبة المكية،

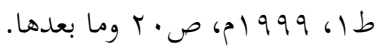

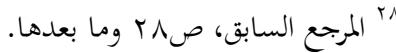

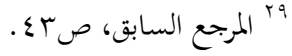




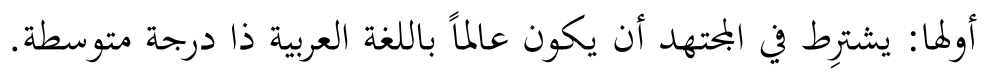

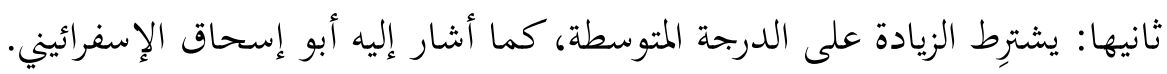

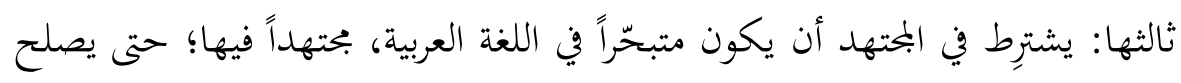

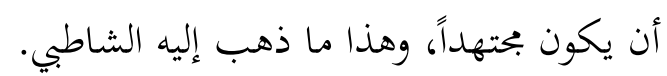

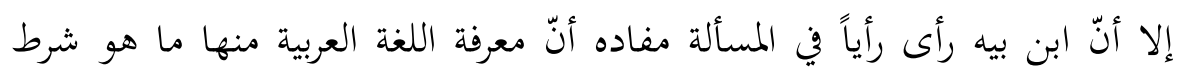

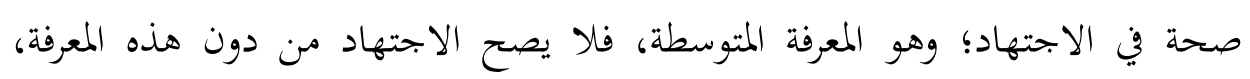

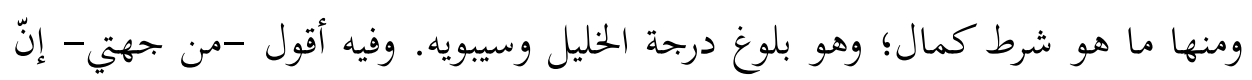

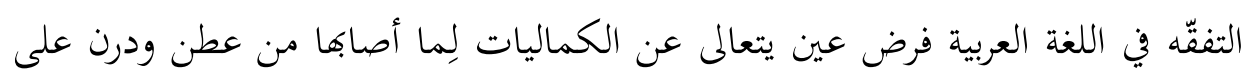

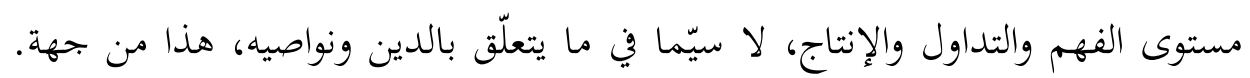

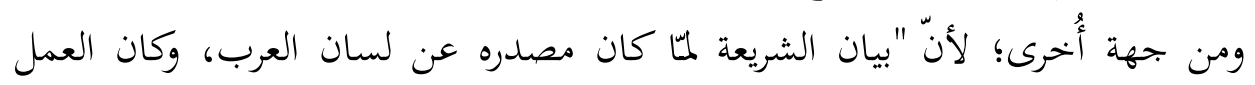

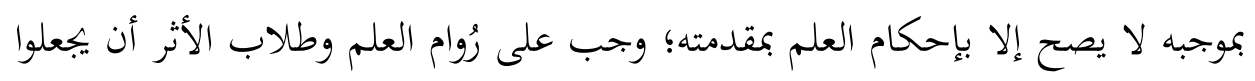

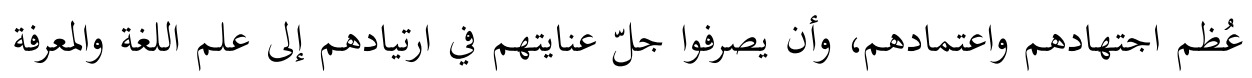

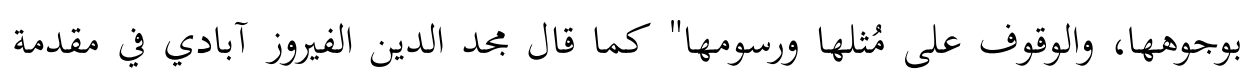
قاموسه المحيط.

\section{رابعاً: دلائل البُعْد اللغوي لمقاصد الشريعة الإسلامية وكشفه عن المصلحة البشرية}

حاولنا - في ما سلف- إثبات وجه التقاطع الممكن بين اللغة والمقصد الشرعي في

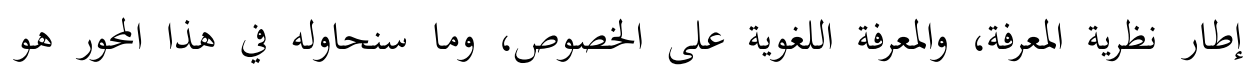

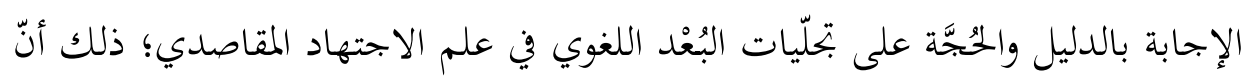

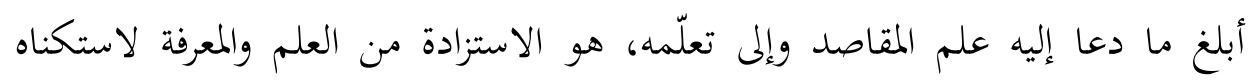

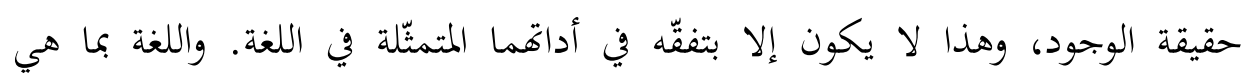

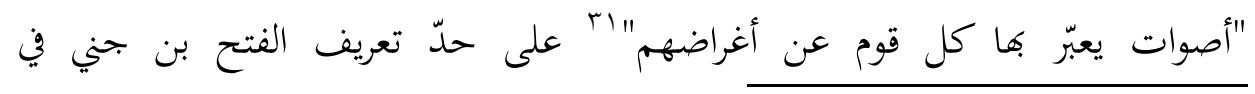

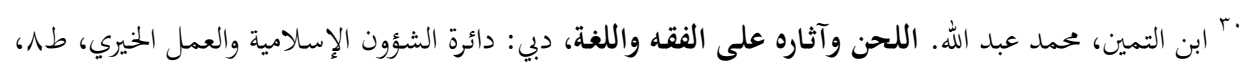

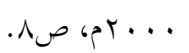

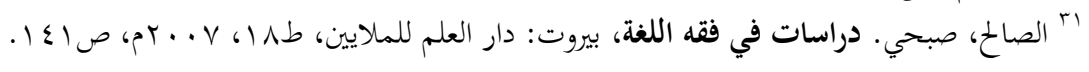


"خصائصه"، فإنّ من أغراض كلّ فرد -لا سيّما المسلم- معرفة المقصد من وجوده، ومن تناسله، ومن عباداته، ومن حريته، ومن درء المفاسد عنه، ومن جلب المصالح إليه، وغيرها

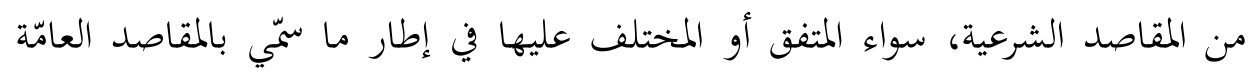
والخاصّة، والقطعية والظنّية؛ حتى تزداد صلته وعلاقته بخالقه عزّ وجلّ، وتحيا في نفسه سموّ

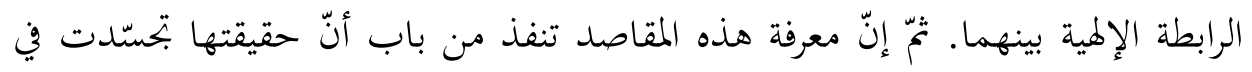

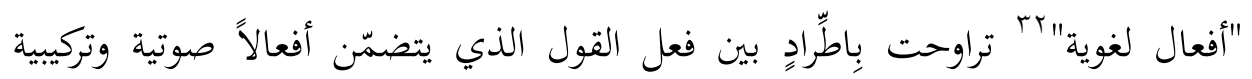
ودلالية، وفعل الإبحاز، وفعل التأثير. غير أنّ هذه الأفعال كلَّها تدور في خحانة الأحكام

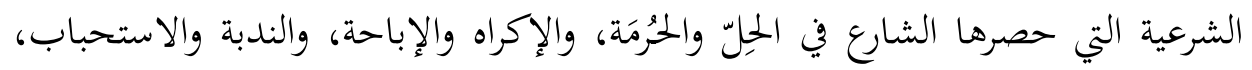

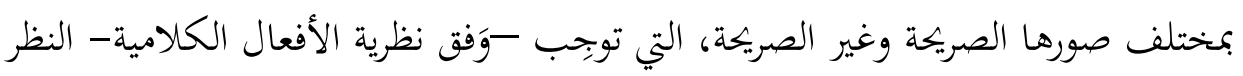

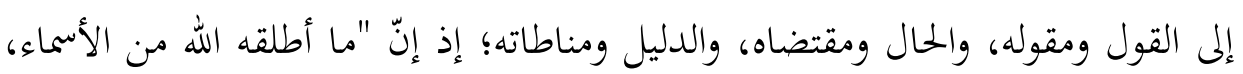

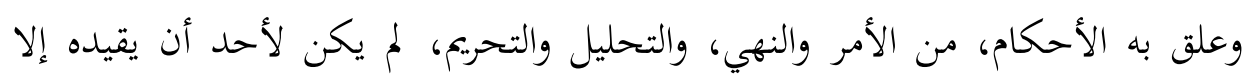

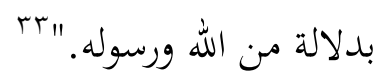

ولفذا الغرض بجد الدكتور نور الدين الخادمي يُفرد مبحثاً مستقلاً في كتابه "الاجتهاد

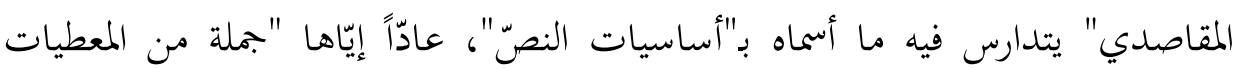
والمعلومات اللغوية والأصولية التي يستحضرها المحتهد في التعامل مع النص الشرعي، فهماً

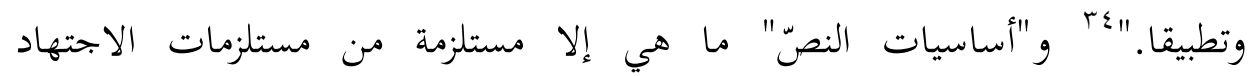

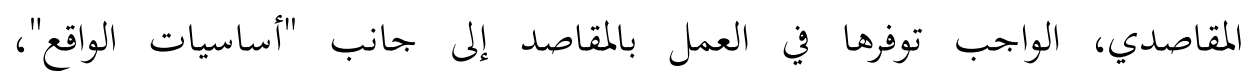
و "أساسيات المكلّف ". على اعتبار أنّ "النص هو الدليل الذي يُراد تطبيق حكمه وعلته ومقصده، والواقع هو ميدان الفعل والتصرف الذي سيكون محكوماً بذلك النص وموجهاً

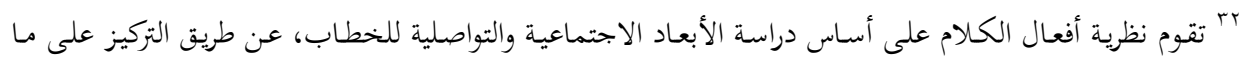

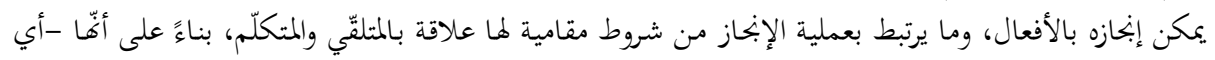

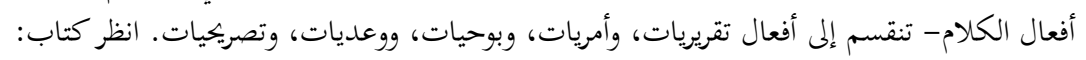
" Quand dire c'est faire "

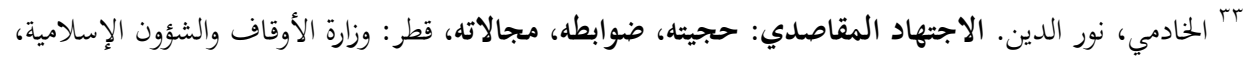

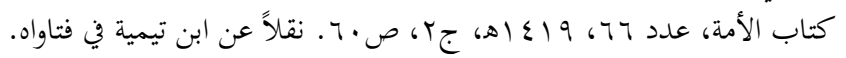

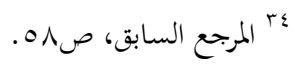




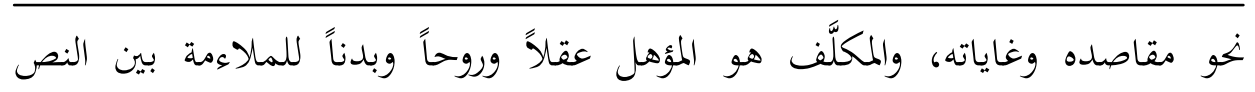

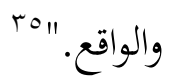

والذي تَغيّاه الخادمي من هذا المبحث، هو التنصيص على "جملة المعلومات اللغوية

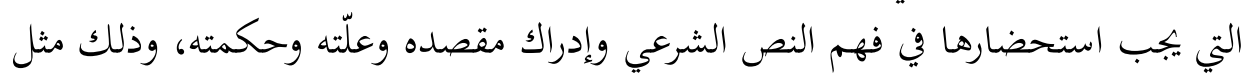

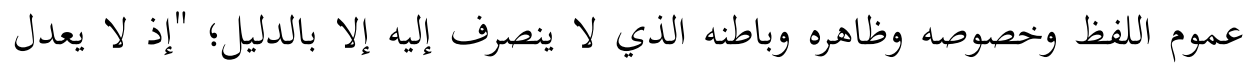

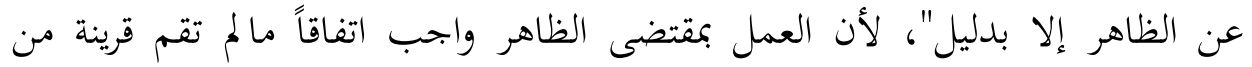
الشرع أو العقل أو اللغة أو العُرف العام تخرجه عن ظاهره، فيؤوّل حينئذ حسبما تقتضيه

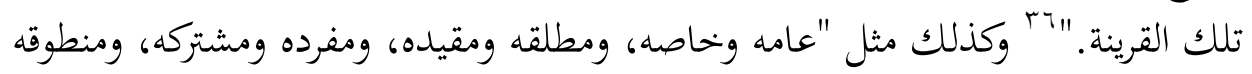

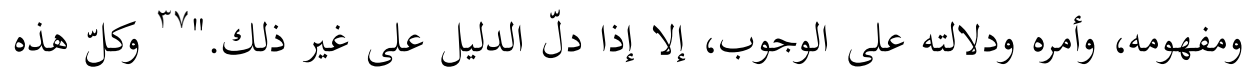

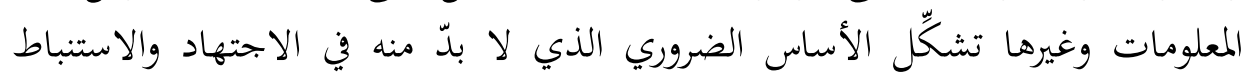

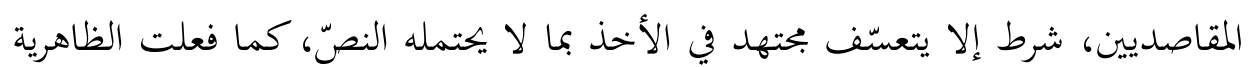

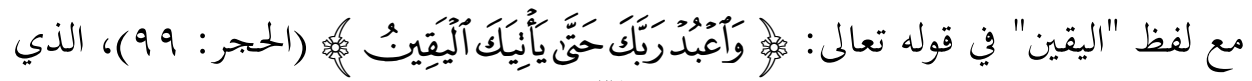

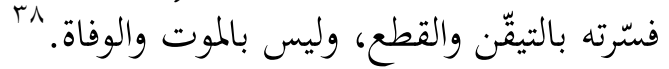

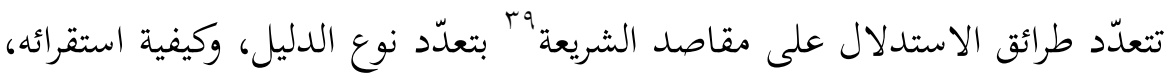
ومن هذه الطرائق طريقة -وهو جوهر مبحثنا- تكون فيها أدلة القرآن واضحة، ينتئي

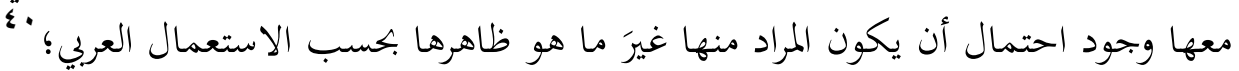

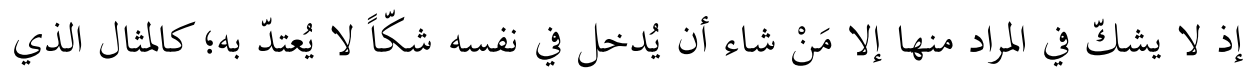

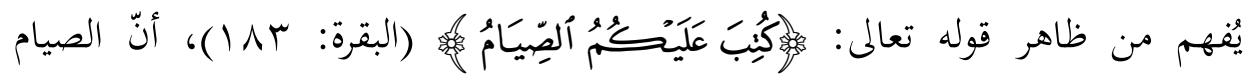

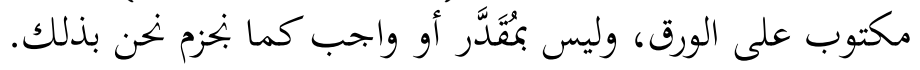
ولكون القرآن مُتواترَ اللفظ قطعيَّه، اء لا يحتاج إلى دليل يوضِّحه؛ فإنّه يحتاج إلى هذا

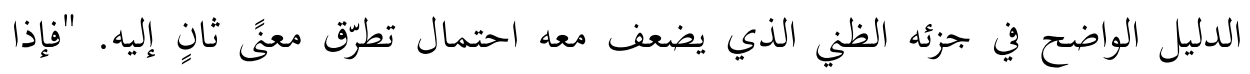

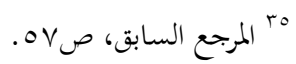

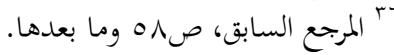

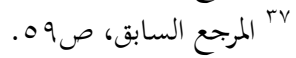

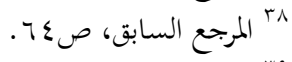

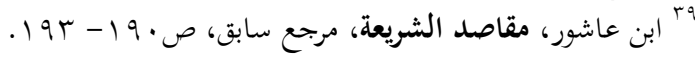

$$
\begin{aligned}
& \text { " أئ، بحسب تداول اللفظ في اللغة العربية. }
\end{aligned}
$$

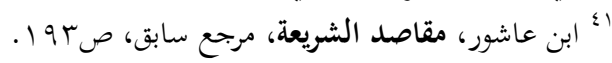


انضم إلى قطعيّة المتن قوةُ ظنّ الدلالة تسنّى لنا أخذ مقصد شرعيِّ منه يرفع الخلاف عند

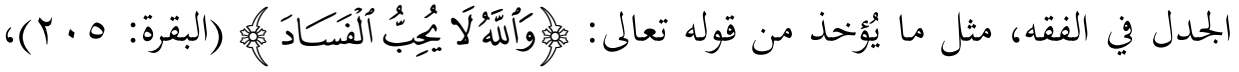

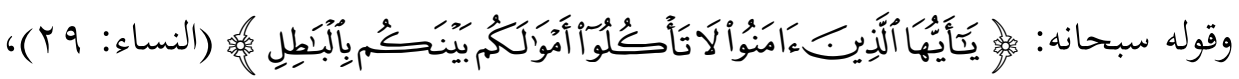

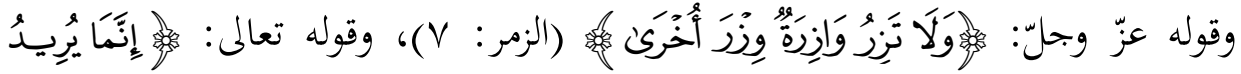

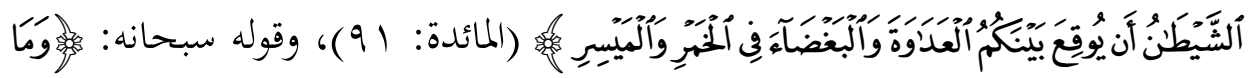

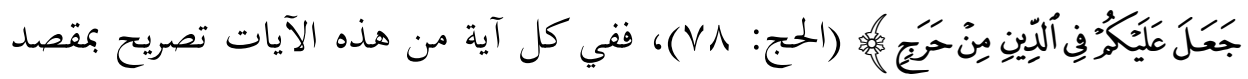
شرعي، أو تنبيه على مقصد. "r"

ولمّا كان الجواب عن سؤال الشاطبي في "موافقاته" الذي يقول فيه: "بماذا يعرف ما

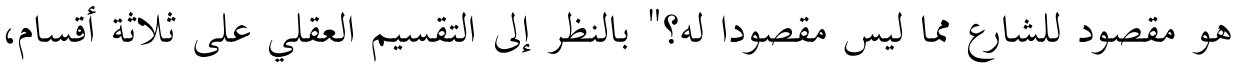

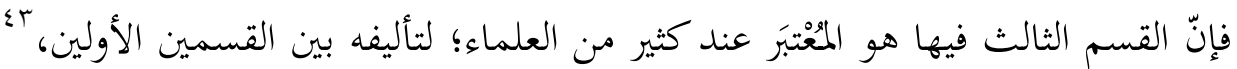

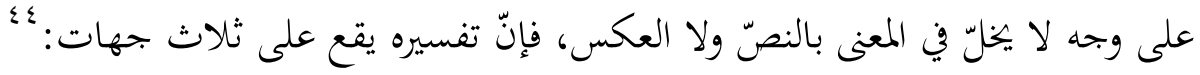
أولاها: بحرّد الأمر والنهي الابتدائي التصريكي. فإن الأمر كان أمراً لاقتضائه الفعل، فوقوع الفعل عنده مقصود للشارع، وكذلك النهي في اقتضاء الكف. ثانيتها: اعتبار علل الأمر والنهي؛ كالنكاح لمصلحة التناسل.... . ثالثتها: أنّ للشارع في شرع الأحكام مقاصد أصلية ومقاصد تابعة، فمنها منصوص

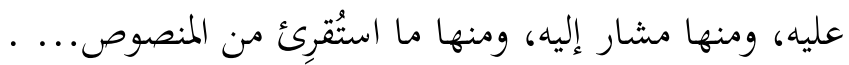

وعلى هذا كانت دلالة ألفاظ اللغات، ودلالة أنواع كلام اللغة الواحدة تتفاوت تفاوتاً في تطرُق الاحتمال إلى المراد بذلك الكاملام؛ إذ إنّ بعض أنواع الكلام يتطرّق إليه

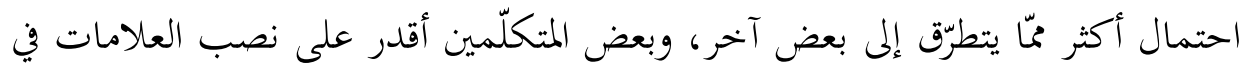

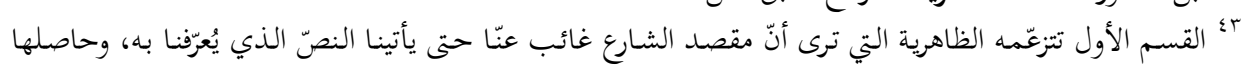

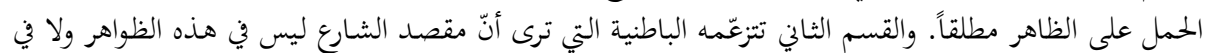

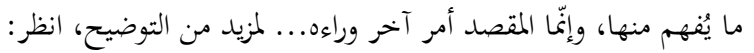

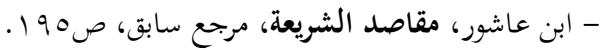

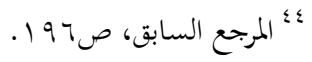




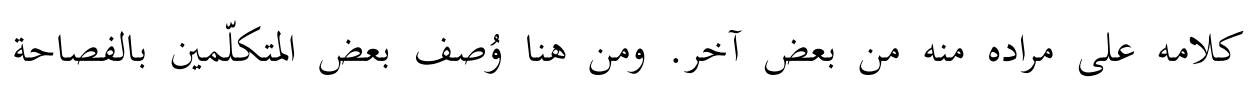

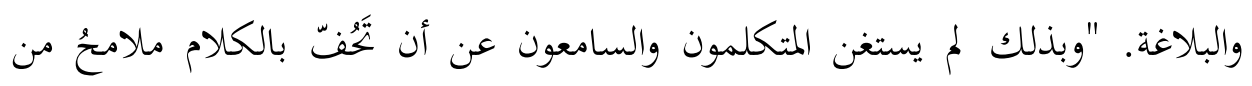

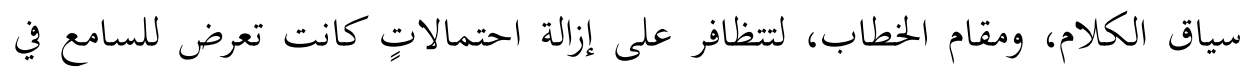

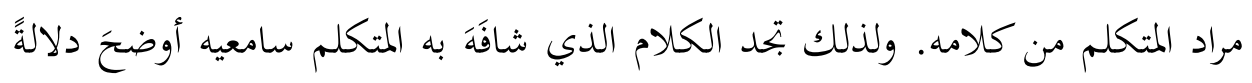

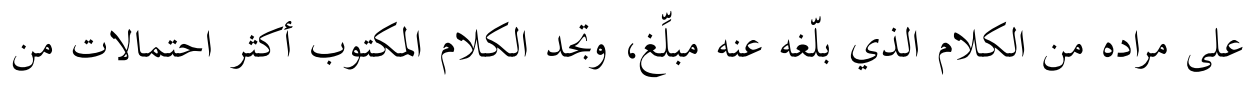

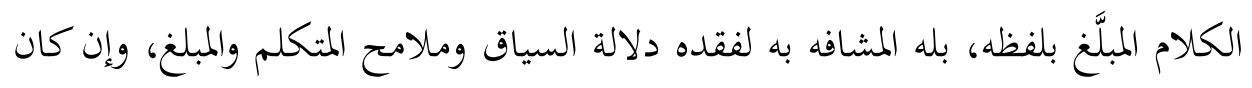

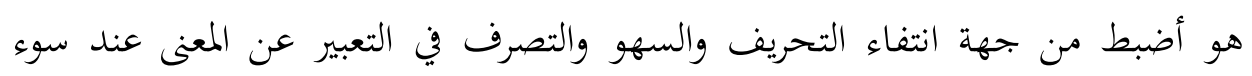

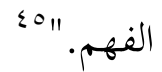

وفي ذات السياق ما أورده الدكتور فؤاد حسني قلع في "مقاصد تصرفات الرسول

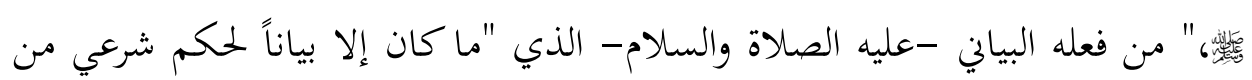

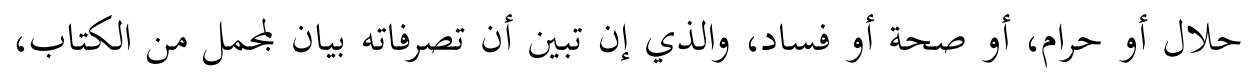

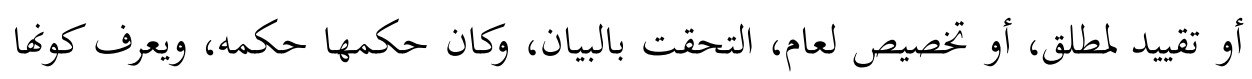

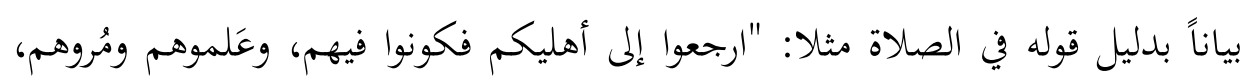

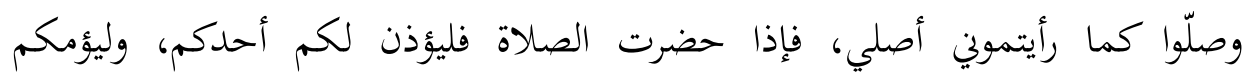

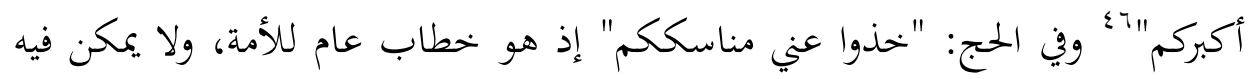

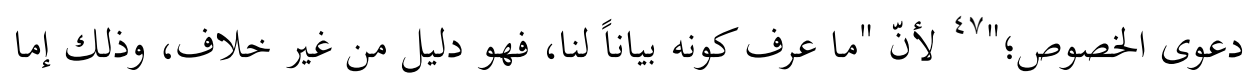

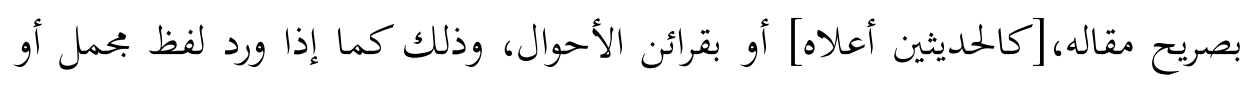

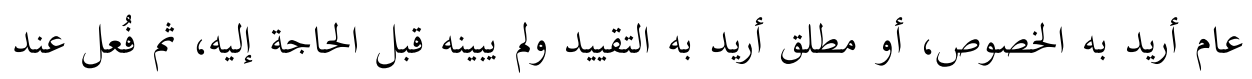

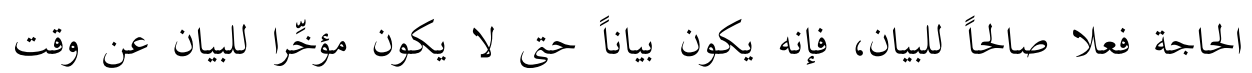

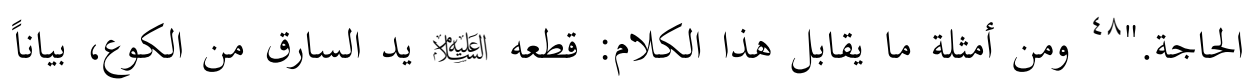

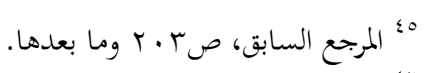

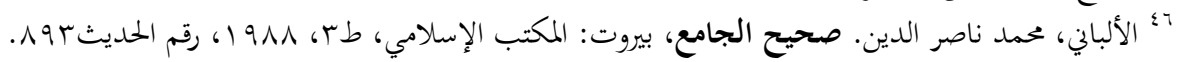

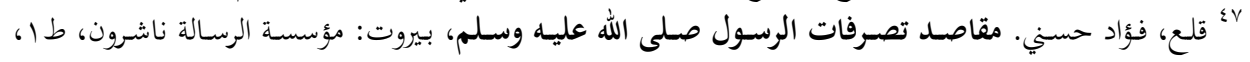




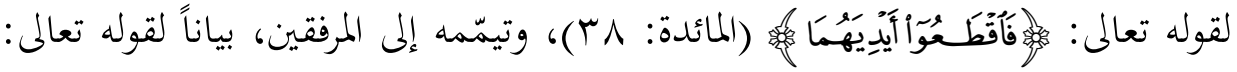

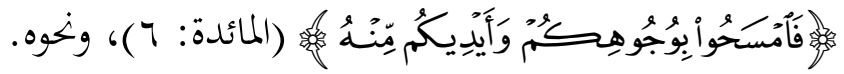

ومن دلائل البُعْد اللغوي في النصّ المقاصدي كذلك، ارتحان الأخير على التصريح

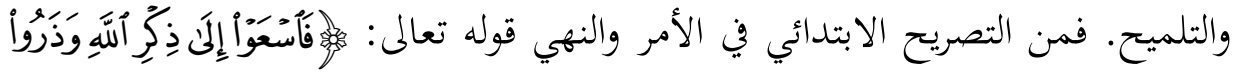

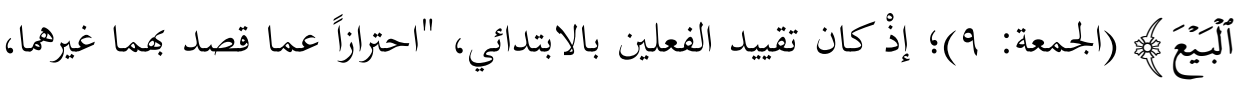

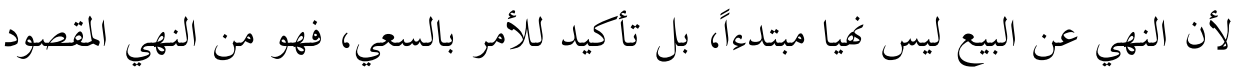

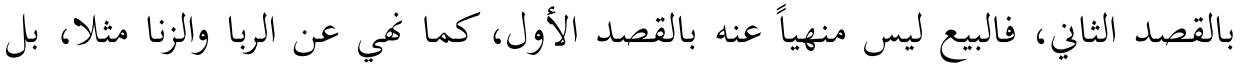

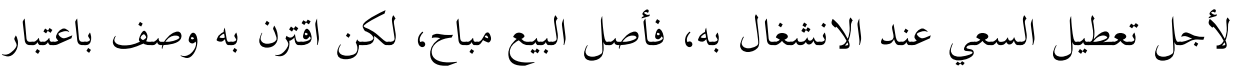

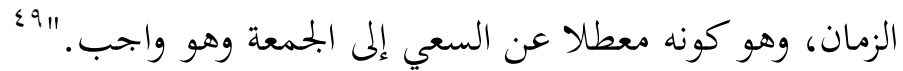

ومن النصوص القطعية التي لا تحتمل أكثر من ظاهرها استناداً إلى قاعدة العلّة،

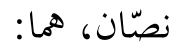

- نصّّ معبّر عن علّّه صراحة وبصيغة قطعية، مستعملاً فيها أدوات من قبيل:

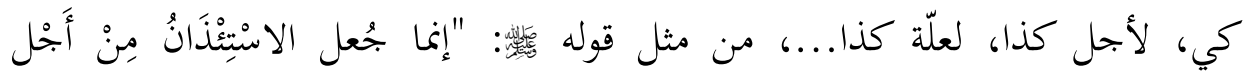

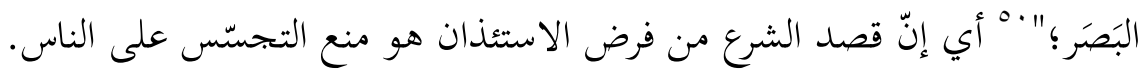
- نصّّ معبّر عن علّّه ليس بصيغة قطعية، وإنمّا بصيغة ظاهرة، والفرق بين

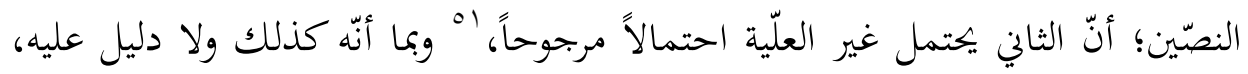

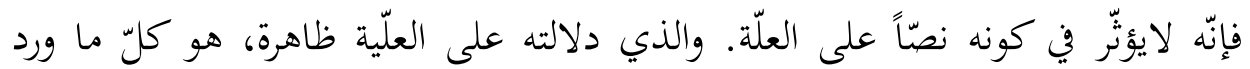

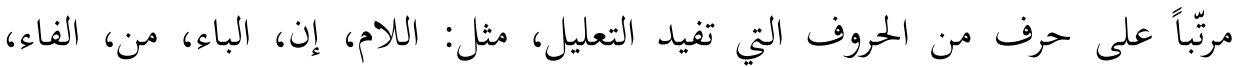

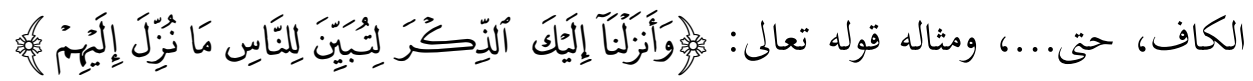
(النحل: § §)، فالمقصد من تكليف الرسل بتبليغ الوحي إلى الناس هو البيان.

9؛ حبيب، حممد بكر إسماعيل. مقاصد الشريعة الإسلامية تأصيلاً وتفعيلاً، مكة المكرمة: دار طيبة الخضراء، طا،

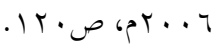

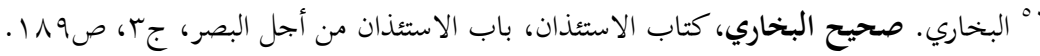

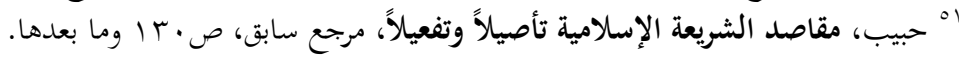


لهذا وذاك؛ كانت المقاصد الشرعية بأسسها ومراميها، وبكليّاتا وجزئياتها،

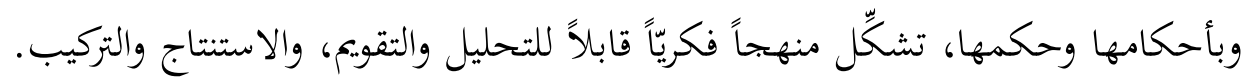

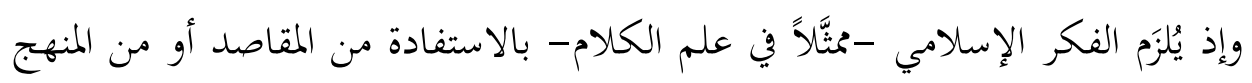
المقاصدي، فإنّ ذلك سيكون من حسناته، فكراً مقاصديّاً يملِّد مقصوده ويقدّره لكي إلكي

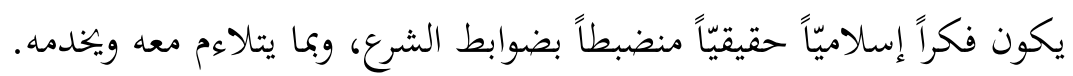
إنّ الذي يتحصّل عندنا في هذا الباب؛ أنّ الخلاف قائم بين العلماء والفقهاء

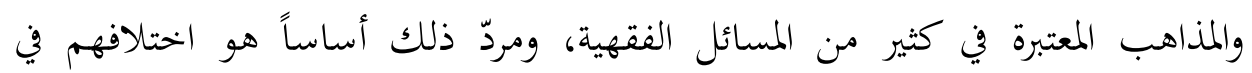
مدلولات بعض الألفاظ اللغوية، على غرار مدلول القبض والتقابض في البيع، ومدلول

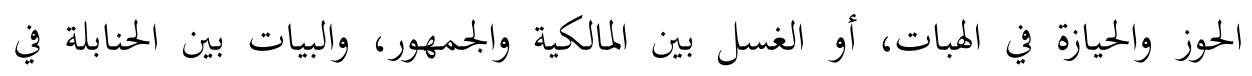

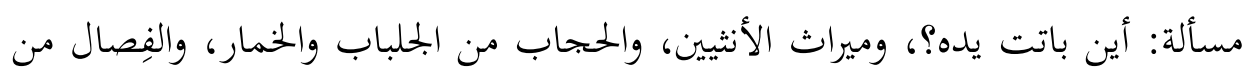

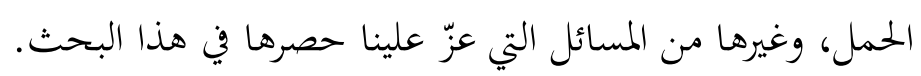

ولعلّنا نكتفي بسرد بحموعة ثانية من النماذج التي ينبني على فهم مدلولاتها حكم

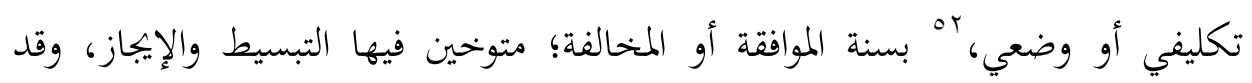
اخترناها من الكلمات والمواقف المرتبطة بالحياة اليومية للفرد المسلم، علماً بأنّ معانيها تباينت بتباين درجة حضور الاستعمال العُري للغة، أو السياق القرآين، على اعتبار أنّه

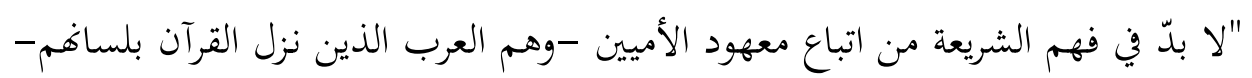

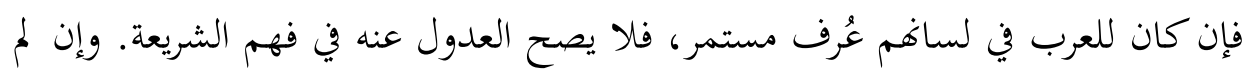

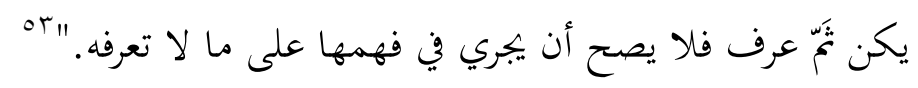

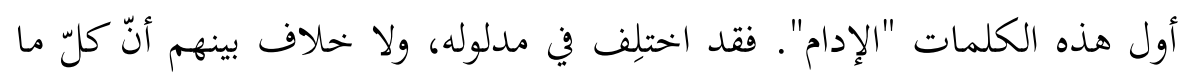
يصطبغ فيه من المائعات؛ كالزيت والسمن والعسل والخلّ، وغير ذلك من الأمراق أنّه

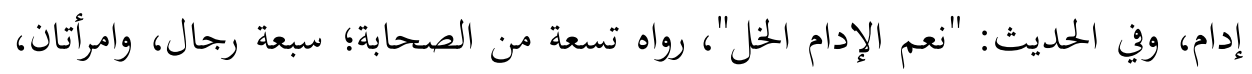

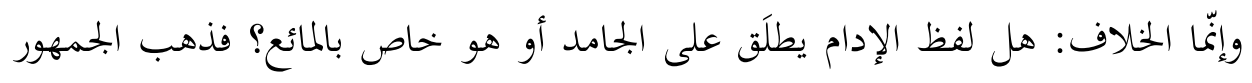

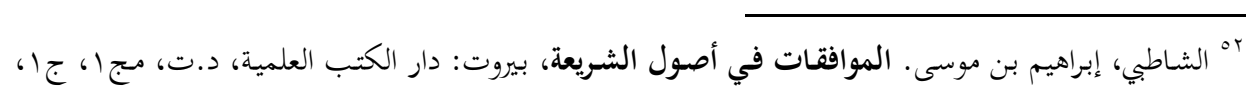

$$
\begin{aligned}
& \text { صזr. } \\
& \text { ror المرجع السابق، مجل، جr، صبr. }
\end{aligned}
$$


إلى أنّ الإدام يججوز إطلاقه على الجحامد؛ كاللحم والتمر، وهذا قول مالك، والشافعي،

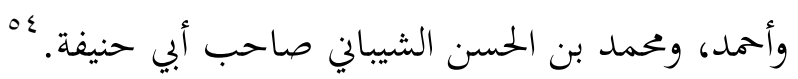

وقال أبو حنيفة -وهي رواية عن أبي يوسف صاحبه- إنّه لا يجيوز إطلاقه على إلى

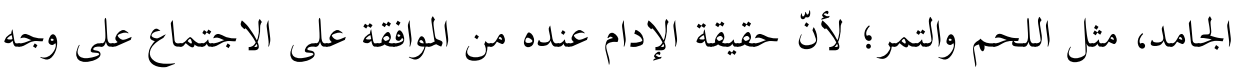

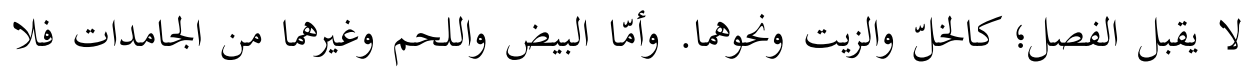

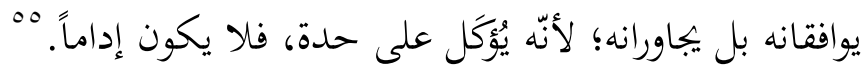

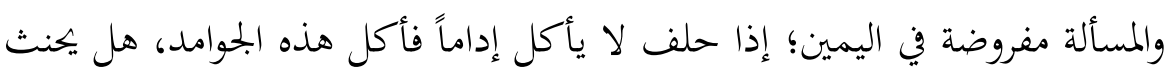

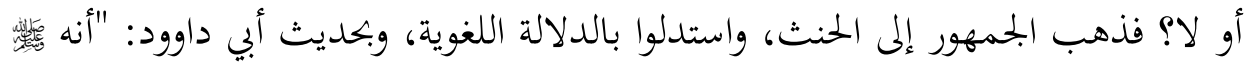
أخذ كسرة من شعير فوضع عليها تمرة فقال: سيد إدامكم الملح."آه وذهب أبو حنيفة

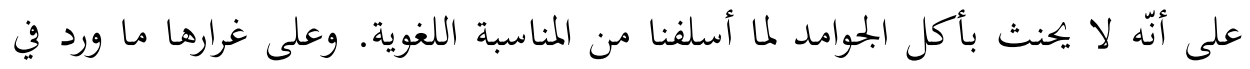

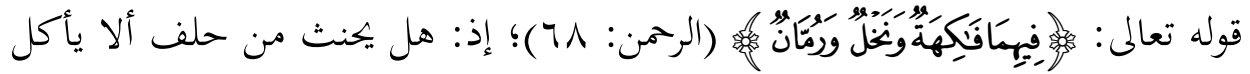

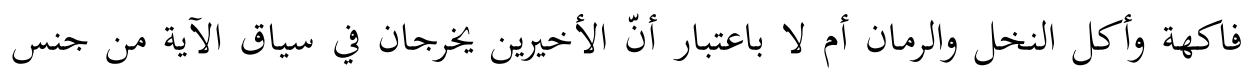

الفاكهة?

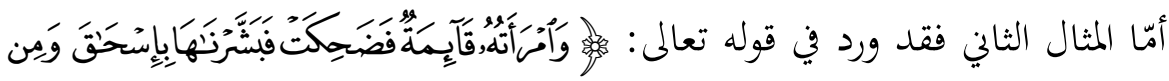

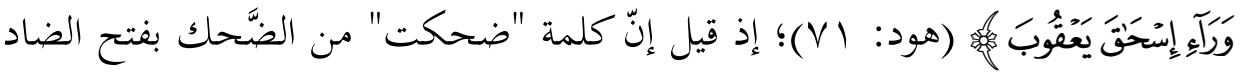

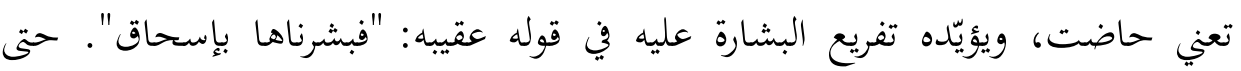

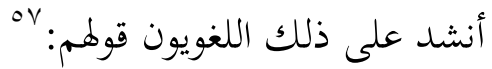

وإِيّ لآتي العرِّس عند طهورها

غير أنّ آخرين أنكروا أن يكون في كلام العرب لفظة "ضحكت" بمعنى "حاضت" فرجّحوا بالمقابل دلالة الضّحك المعروف الذي هو ضد البكاء، ثمّ اختلفوا في توجيه سببه. وأقرب الوجوه قول مقاتل: إنّ المرأة ضحكت من من خوف فروف إبراهيم ورِعدته من ثلاثة

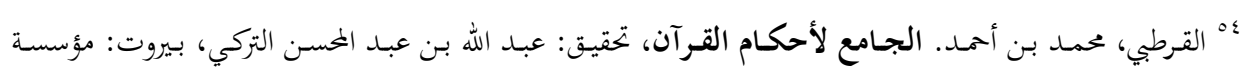

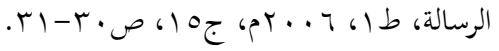

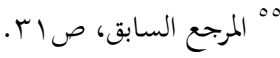

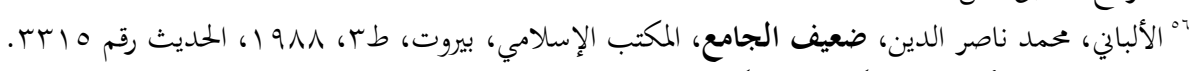

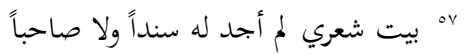




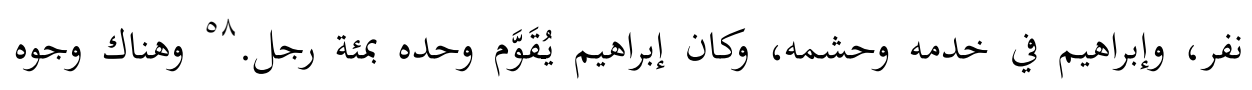

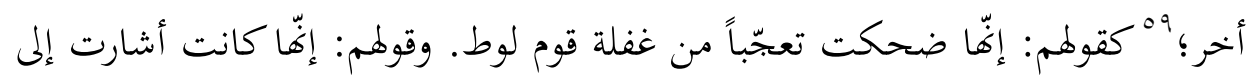

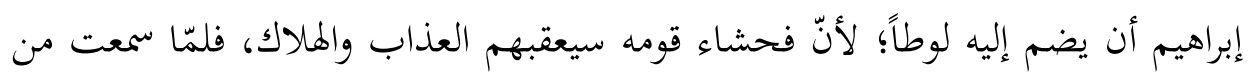

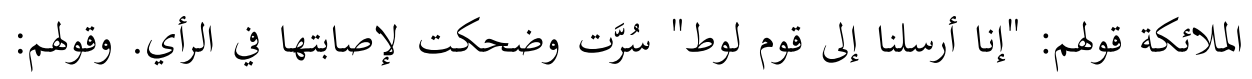

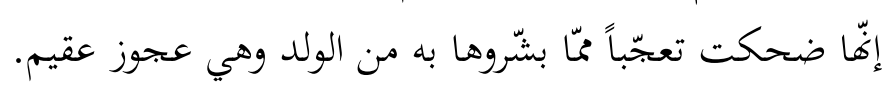

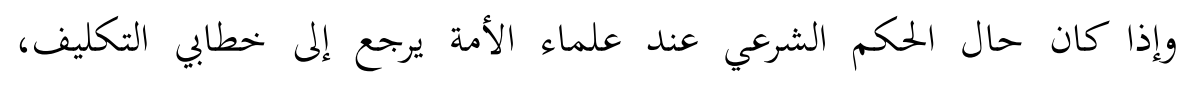

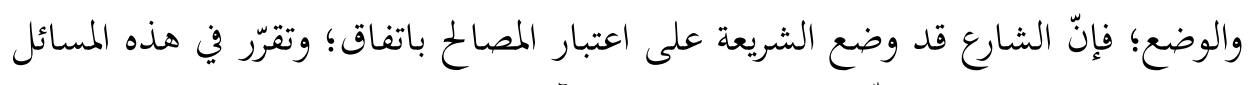

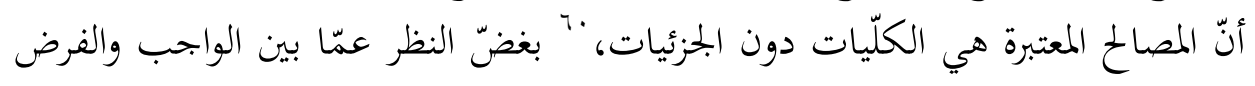

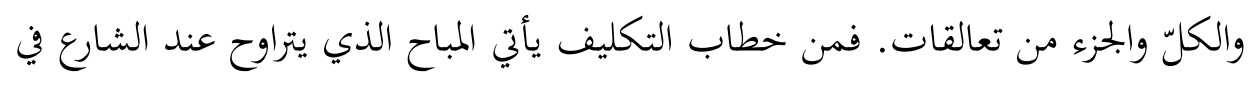

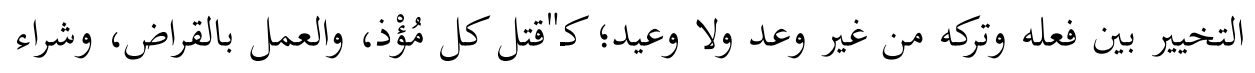

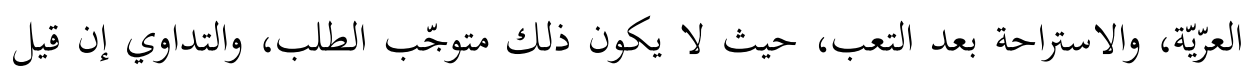

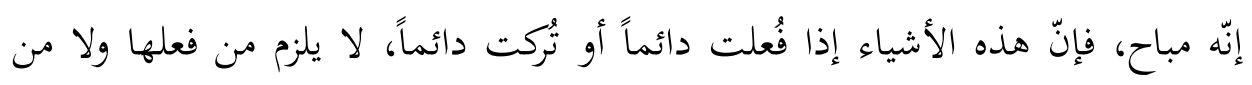

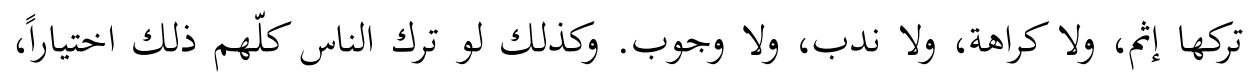

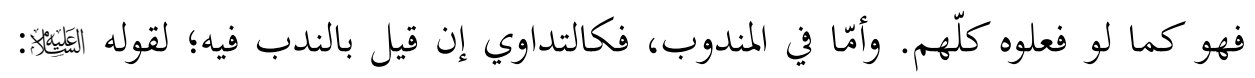

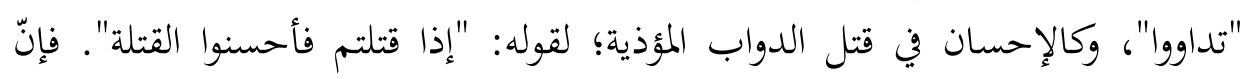

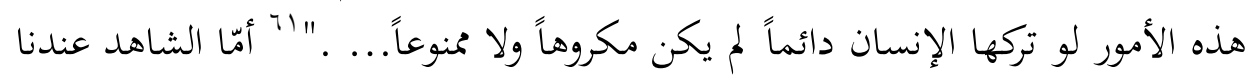

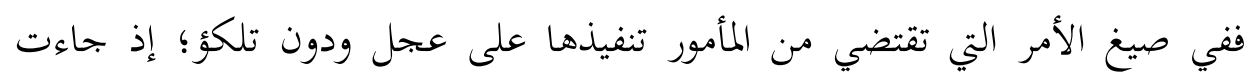

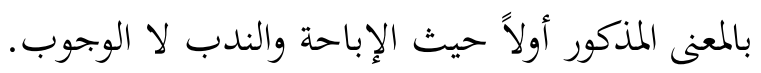

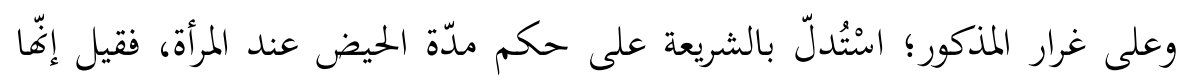

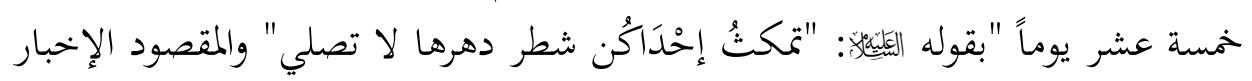

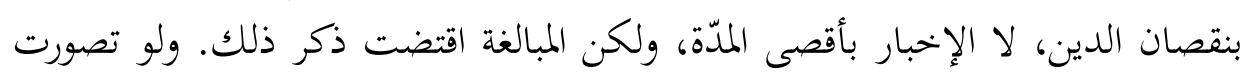

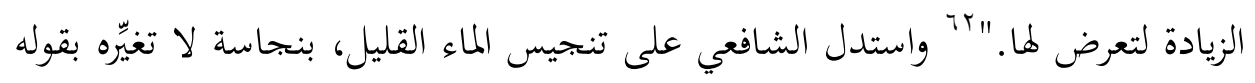

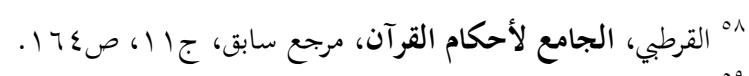

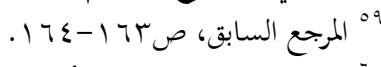

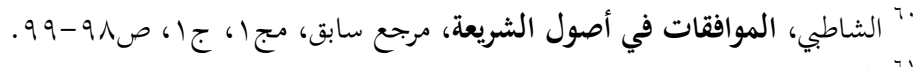

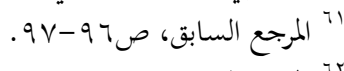

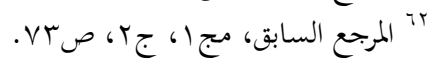




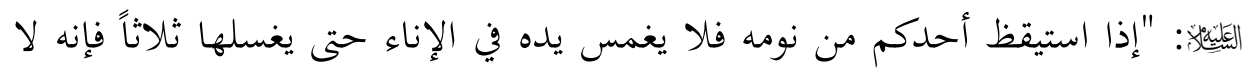

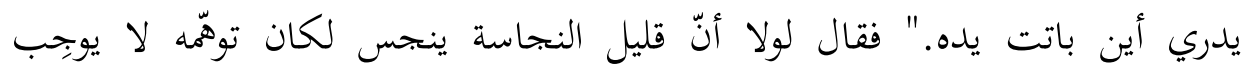

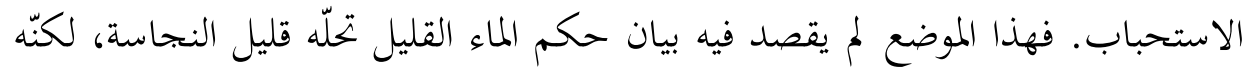

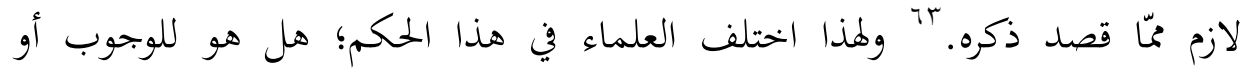

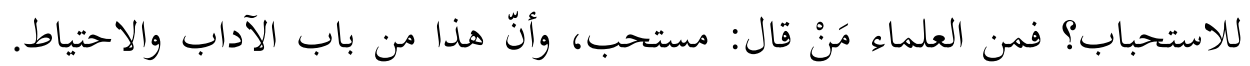

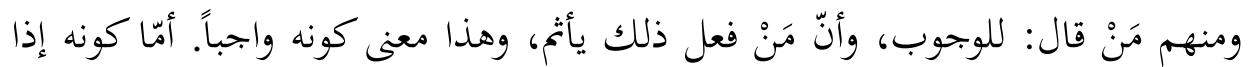

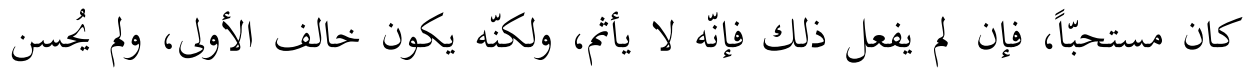

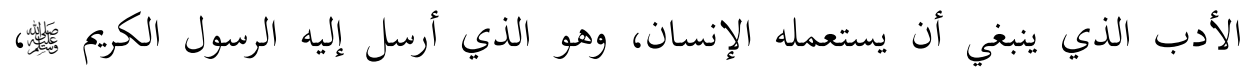

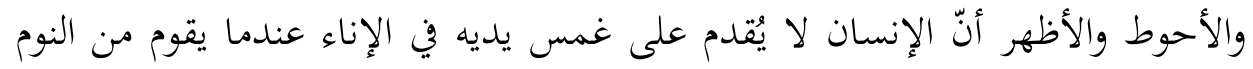

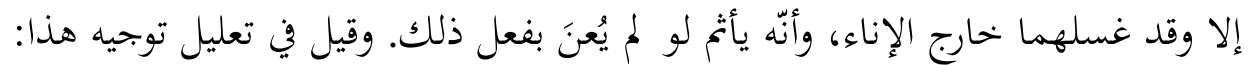

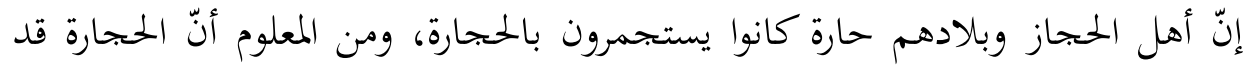

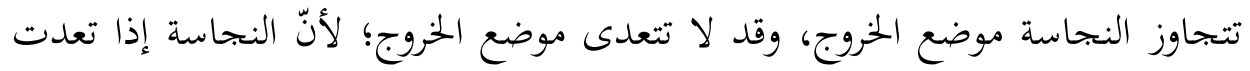
موضع الخروج كفى الاستنجاء.

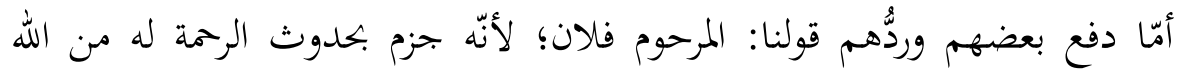

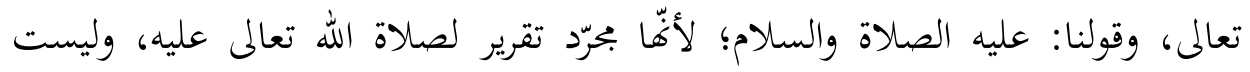

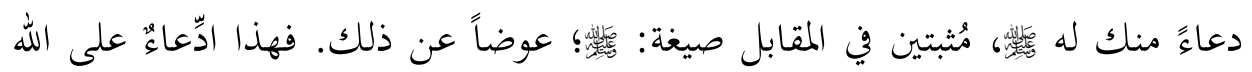

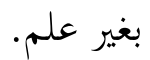
ذلك أنّ المسألة -إذا عدنا إلى جوهرها- لا تعدو أن تكون خلافاً في فهم لغة

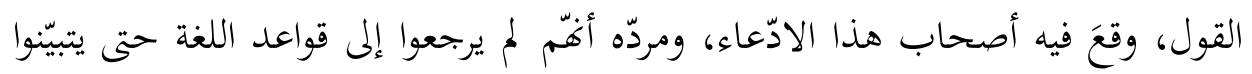
صحة دعواهم من بطلاغما.

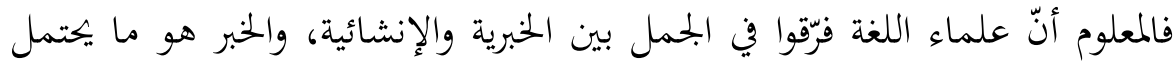

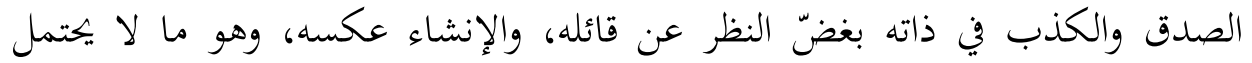

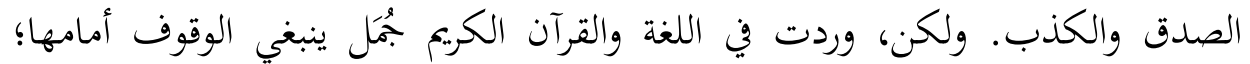

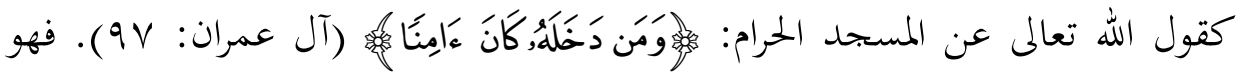

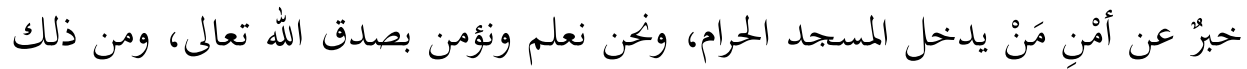




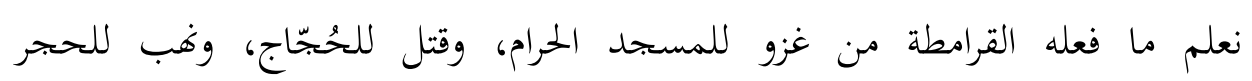

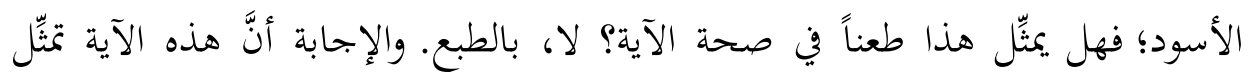

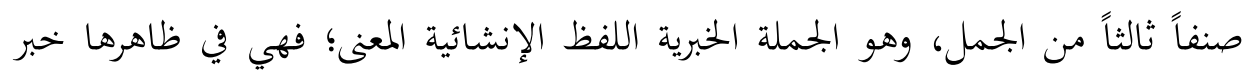

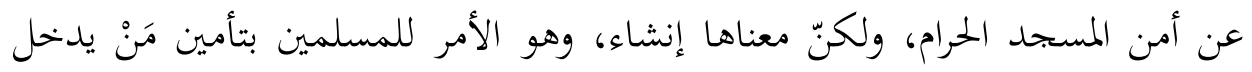

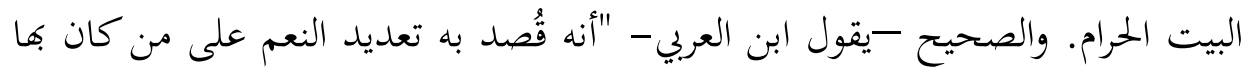

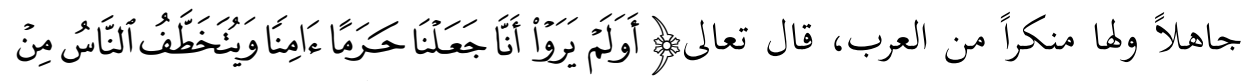

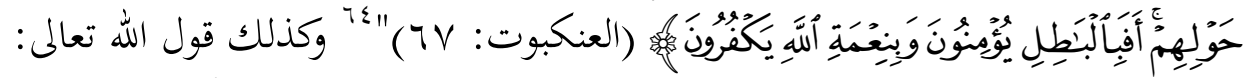

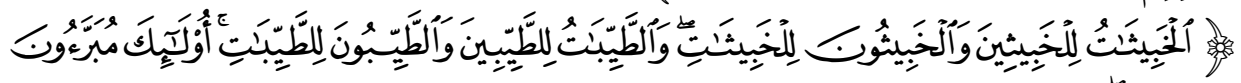

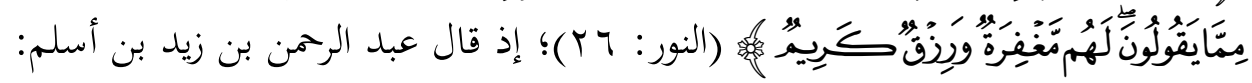

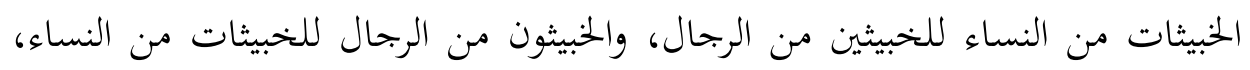

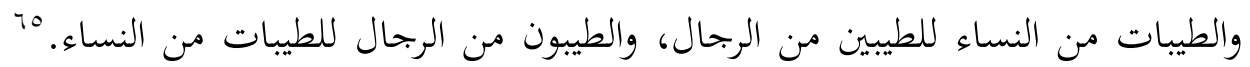

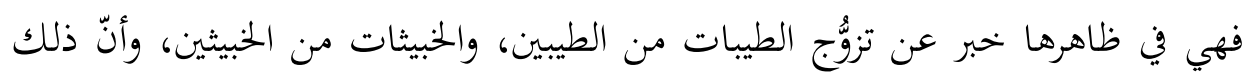

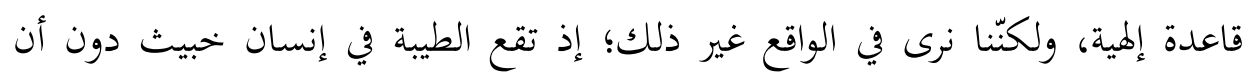

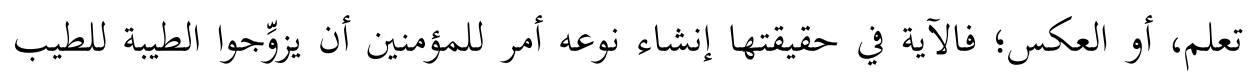
والخبيثة للخبيث؛ حتى يستقيم مسار الحياة.

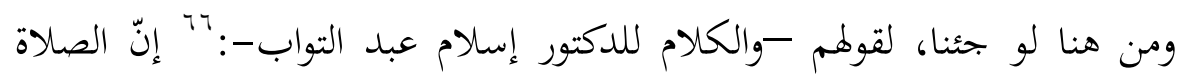

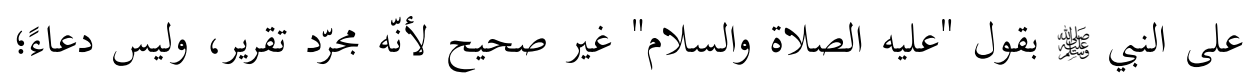

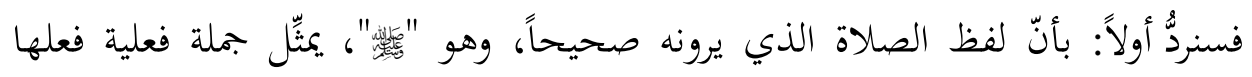

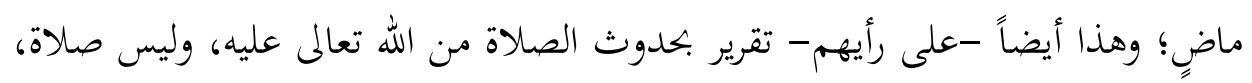

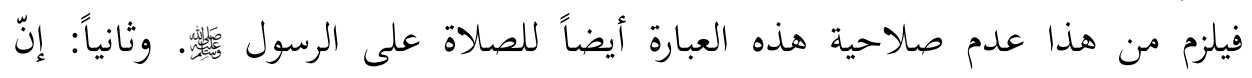

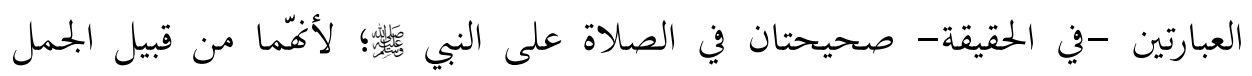

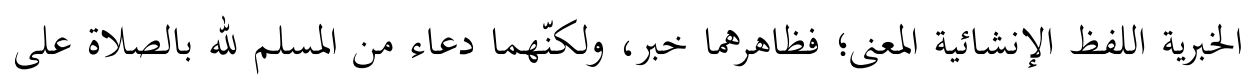

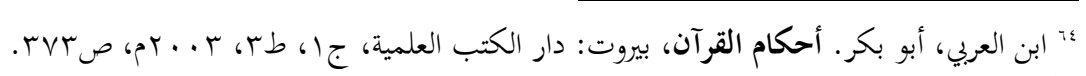

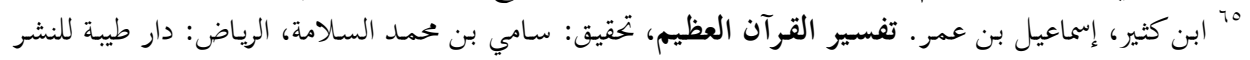

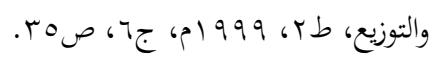

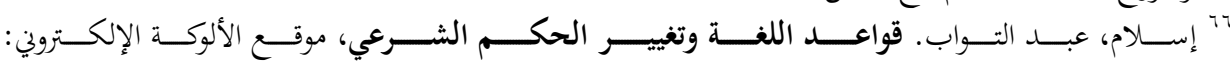
http://www.alukah.net/Literature_Language/1175/6846/ 
النبي

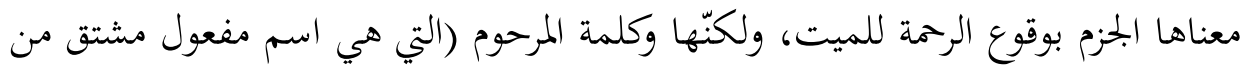

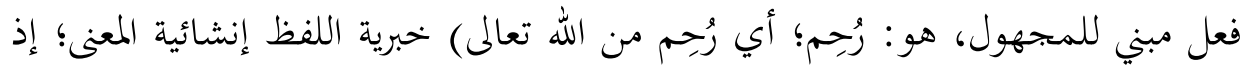

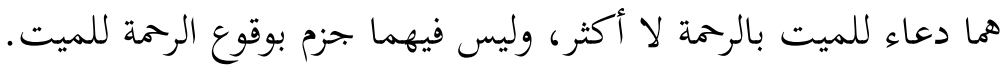

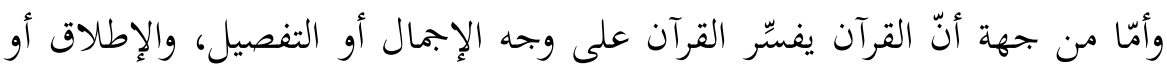

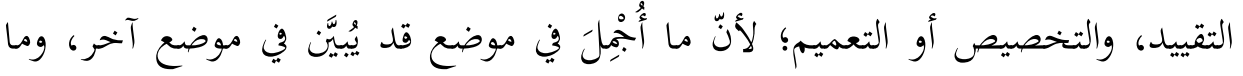

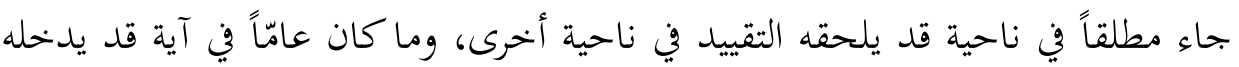

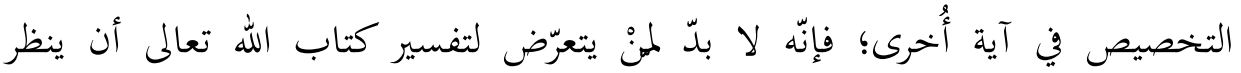

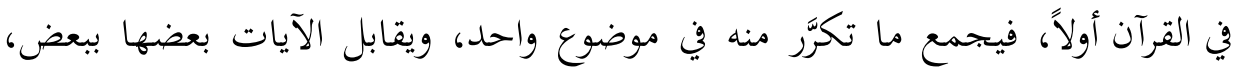

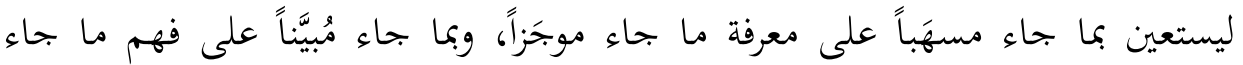

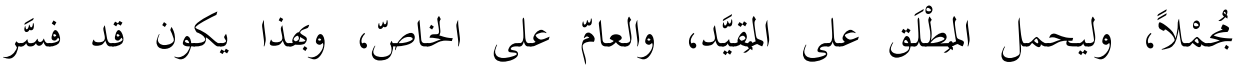

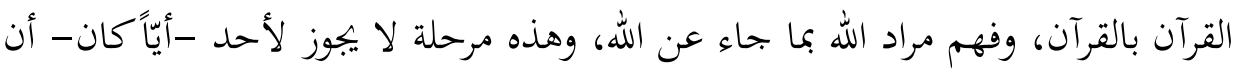

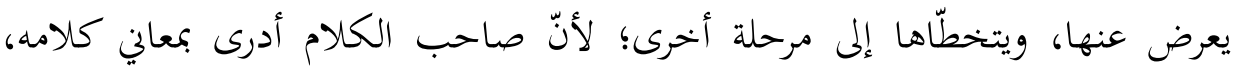
وأعرف به من غيره. ولعلّ هذا ما ننشده من توقِّنا عند آيات (الحجاب) التي كان

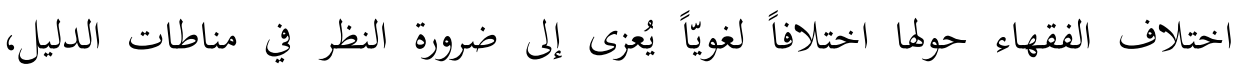
وسياقات الآيات التي وردت فيها مصطلحات الجلباب والخمار والحجاب.

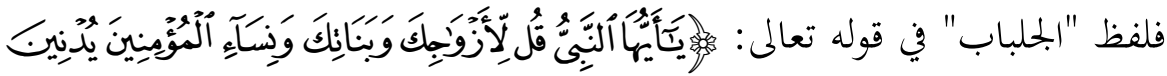

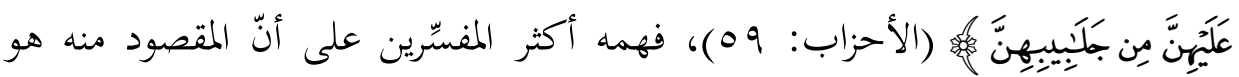

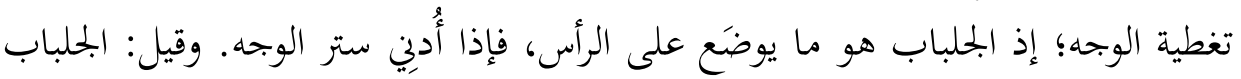

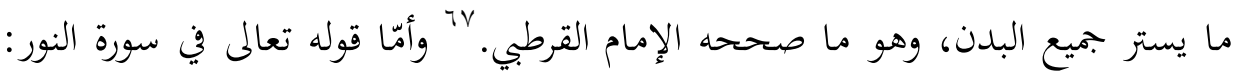
هو

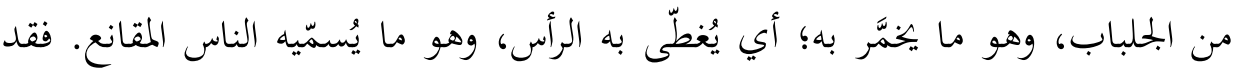

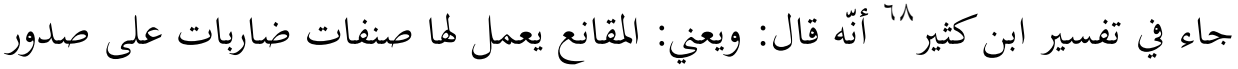


النساء، لتواري ما تحتها من صدرها وترائبها، ليخالفن شعار أهل الجاهلية، فإهن لم يكن يفعلن ذلك، بل كانت المرأة تمر بين الرجال مسفحة بصدرها، لايواريه شيء... فأمر الله

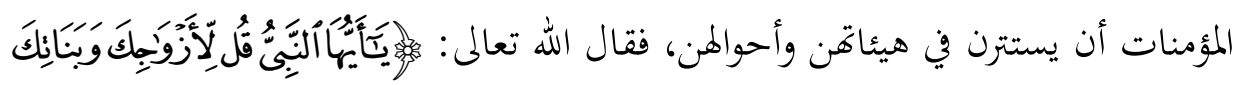

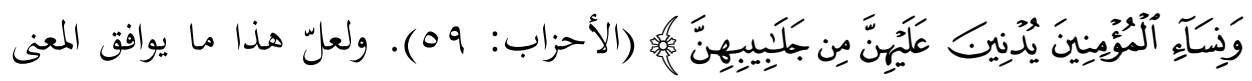

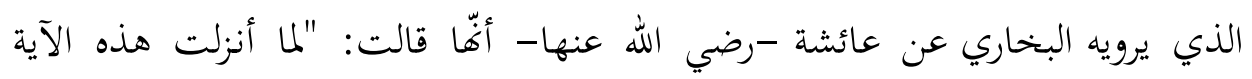

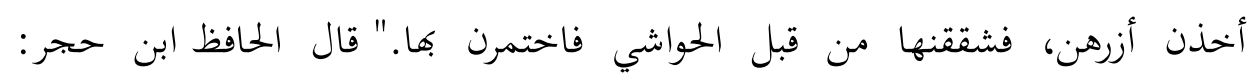
(فاختمرن)؛ أي غطين وجوههن. وقال محمد بن سيرين: سألت عبيدة السلماني عن قوله

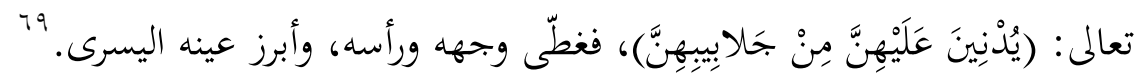

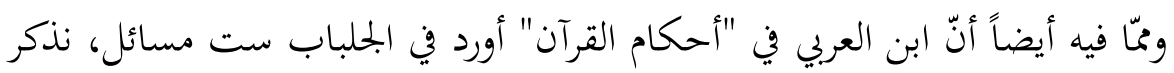

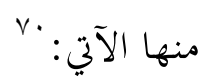
- - جَلْد عمرُ بن الخطاب ابنَ عمّته حين رآها غير مختمرة بين أعلاج قائمة بسوق

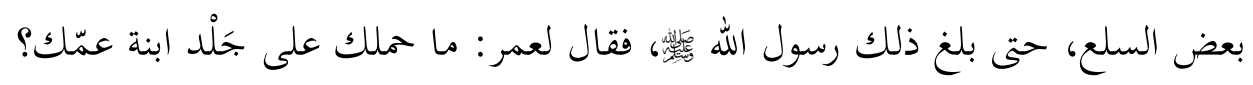
فأخبره خبرها. فقال: وابنة عمّي هي يا رسول الله أنكرقا إذ لم أرَ عليها جلباباً فظنتنها وليدة؛ فنزلت الآية. - - اختلاف الناس في الجلباب، وعلى ألفاظ متقاربة، عمادها أنّه الثوب الذي يُّتر به البدن، لكنّهم نوّعوه ههنا. فقد قيل: إنّه الرداء، وقيل: إنّه القناع.

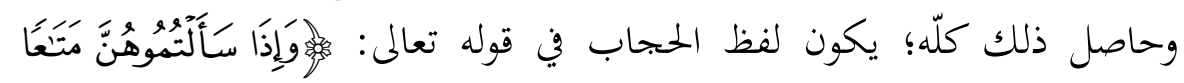

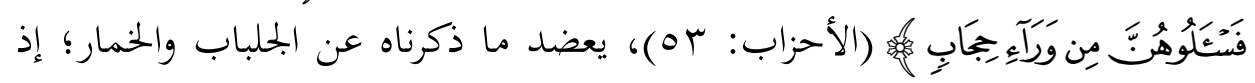

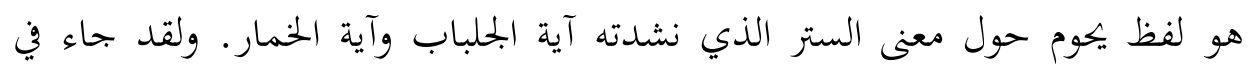

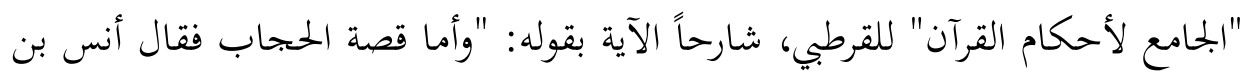

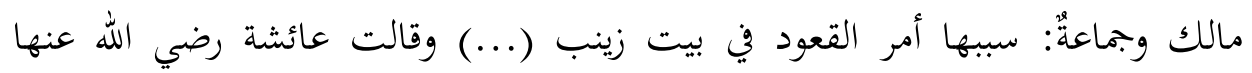

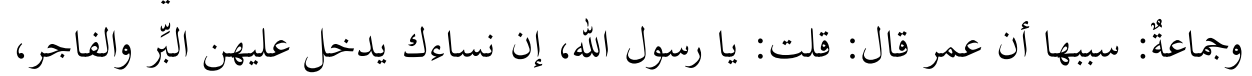

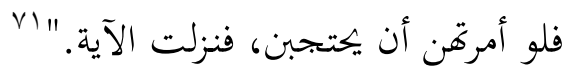

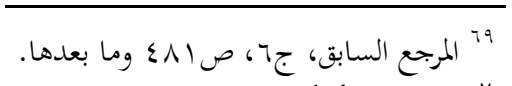

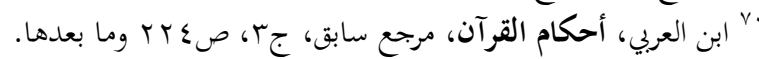

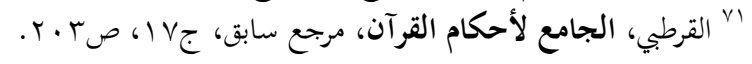


ولقد تنبّه ابن السيد - كما ذكر ذلك الشاطبي في موافقاته- لأسباب الخلاف الواقع

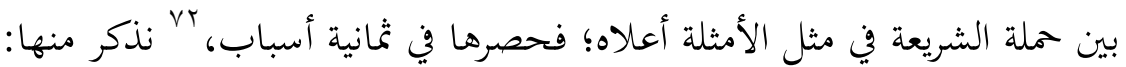
- الاشتراك الواقع في الألفاظ، واحتمالها للتأويلات؛ كالاشتراك في موضوع اللفظ المفرد، مثل: "القرء" الذي يطلَق على الأطهار وعلى الحيض، ولفظ "عسعس" الذي يشترك بين الإقبال والإدبار.

- - دوران اللفظ بين الحقيقة والمحاز؛ كالذي يرجع إلى أحوال اللفظ المفرد، نحو قوله

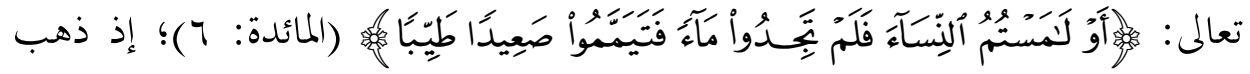
بعض فقهاء الشافعية إلى أنّ المراد بـلامستم" يعمّ الوطء واللمس، وخحالف آخرون فقالوا إنّ المراد هو الوطء فقط. ومناط الحنلاف هو معنى المسّ في الآية؛ هل المراد به المعنى الحقيقي وهو اللمس باليد، أم المعنى البمازي الذي هو الوطء؟

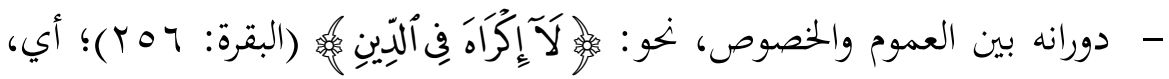
هل هو خبر حقيقي؟ أي، لا يتصوّر الإكراه فيه بعد دلائل التوحيد، وما يظهر إكراهاً فليس في الحقيقة بإكراه. أم هو خبر بمعنى النهي؟ أي، لا تكرهوا في الدين وبتبروا عليه. وعليه، فهو عامّ منسوخ بآية "جاهد الكفار والمنافقين"، أو مخصوص بأهل الكتاب الذين قبلوا الجزية. - مقوعه بين التقييد والإطلاق، وحاله أنّ الفقهاء قد اتفقوا على أنّ الخطاب إذا

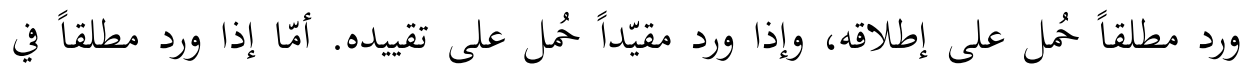
موضع، ومقيّداً في موضع آخر، واختلفا في السبب دون الحكم؛؛ كإطلاق الرقبة في كفّارة

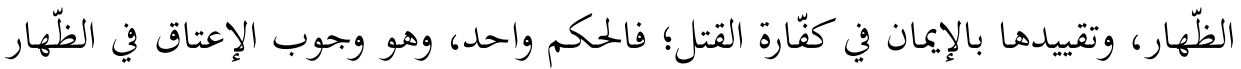

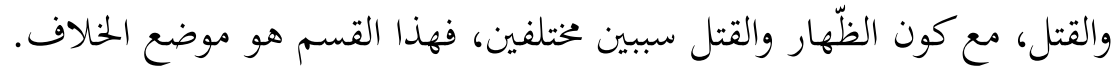
ومن منطق السببين الأولين تحضر قضية ميراث المرأة التي اختلفت حولها العديد من الآراء؛ لاختلاف العلّة التي استند إليها الفقيه في استنباط حكمه. وبذلك يمكننا أن نوضِّح بعض أسباب الاختلاف في ميراث المرأة من خلال الآتي:

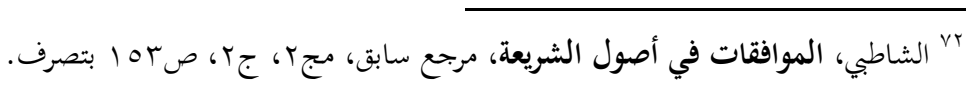




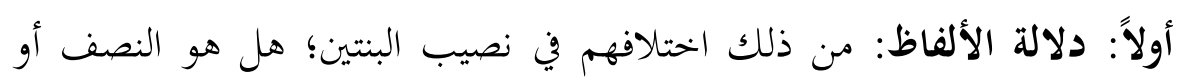

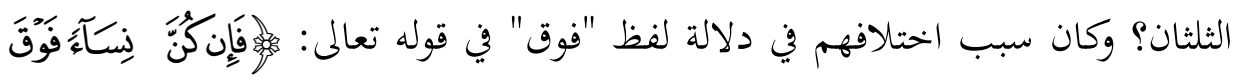

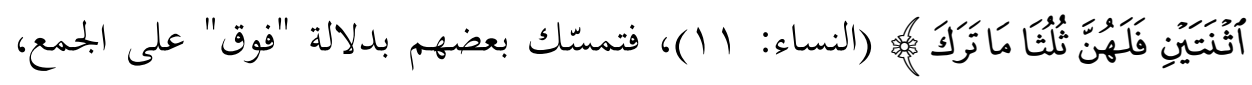

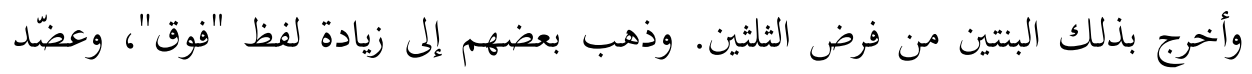
ذلك بأدلة أُخرى، وجعل للبنتين الثلثين.

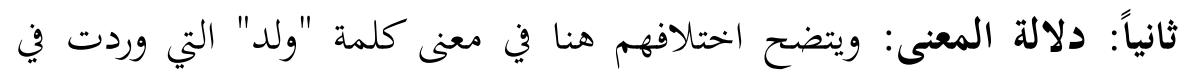

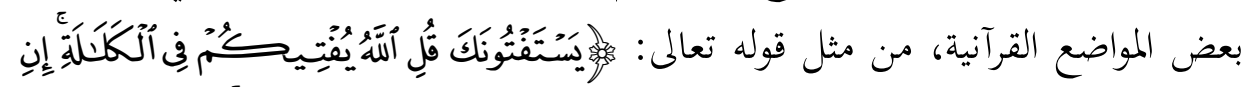

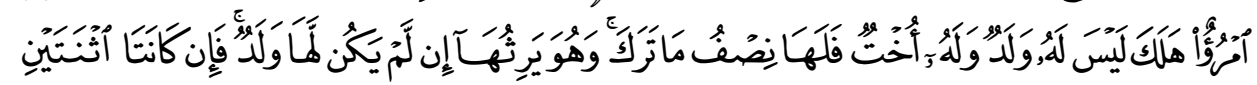

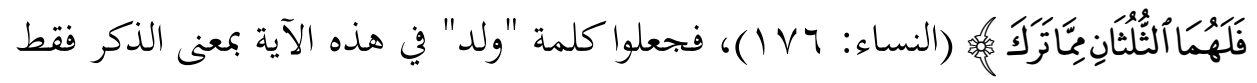

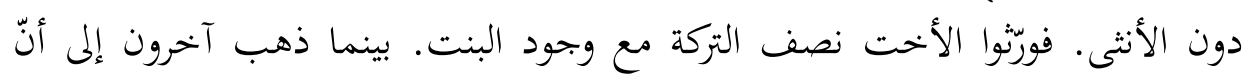

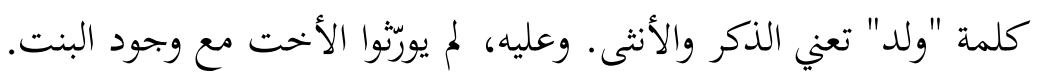

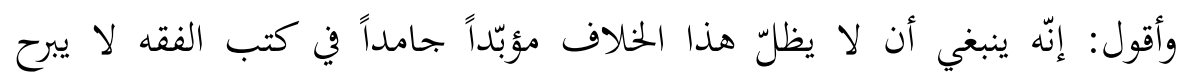

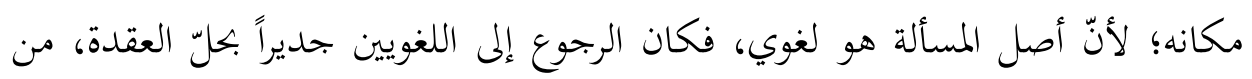

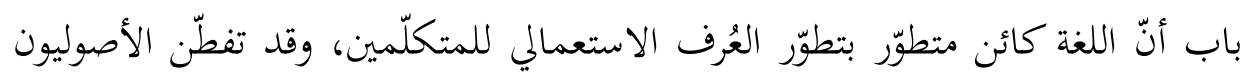

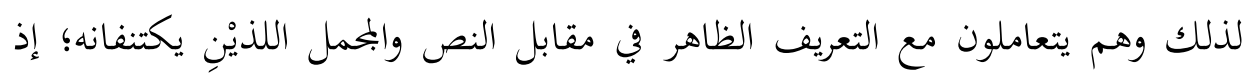

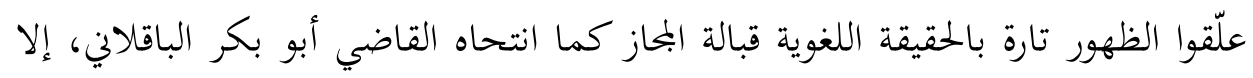

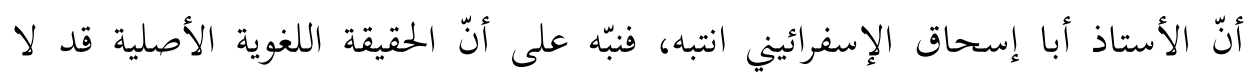

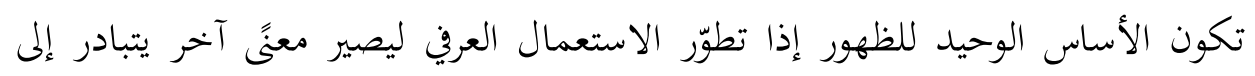

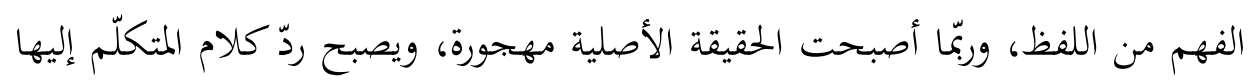
من باب التأويل الذي يقتضيه سياق الآيات.

\section{خامساً: الإعجاز اللغوي أبلغ مقصد شرعي}

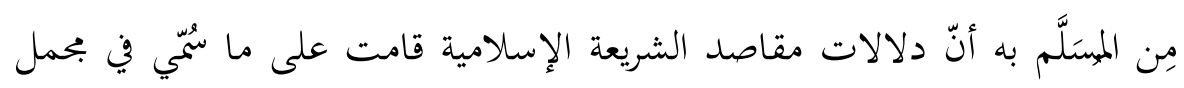

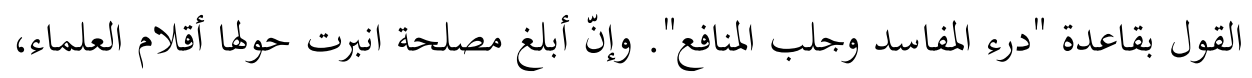




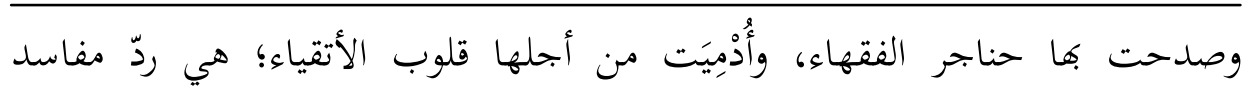

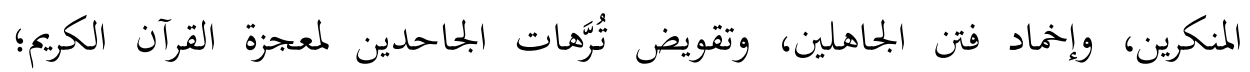

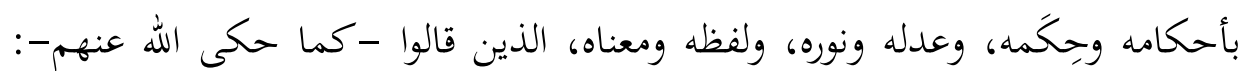

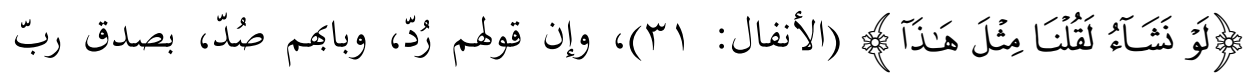

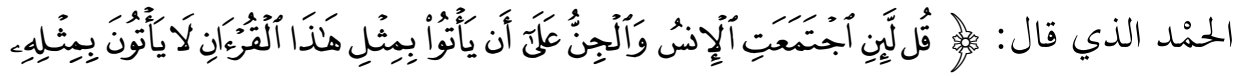

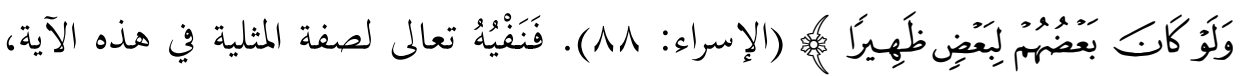

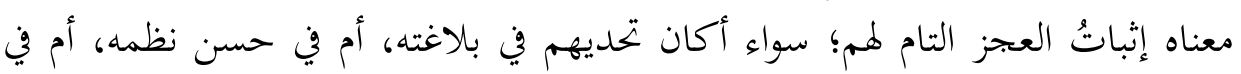
إخباره عن المغيبات، أم في غير ذلك من وجوه الإعجاز .

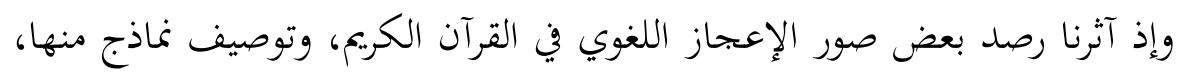

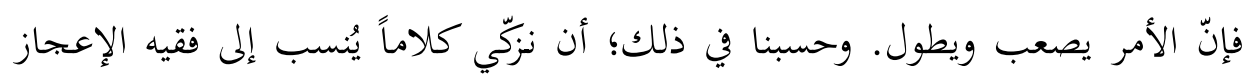

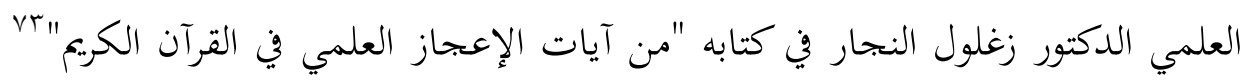
حين قال: "كل نبي وكل رسول قد أوتي من الكرامات ومن المعجزات ما يشهد له له بالنبوة أو بالرسالة، وكانت تلك المعجزات مما تميز فيه أهل عصره:

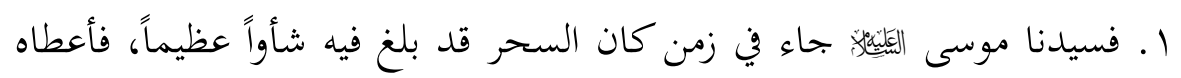
الله تعالى من العلم ما أبطل به سحر السحرة.

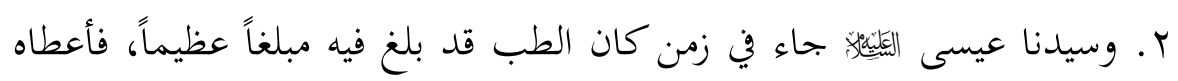
الله تعالى من العلم ما تفوق به على طب أطباء عصره.

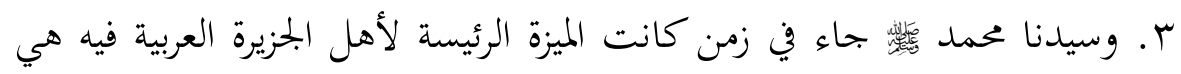
الفصاحة والبلاغة وحسن البيان. فجاء القرآن يتحدى العرب، وهم في هذه القمة من

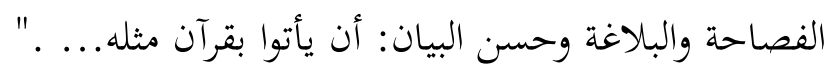

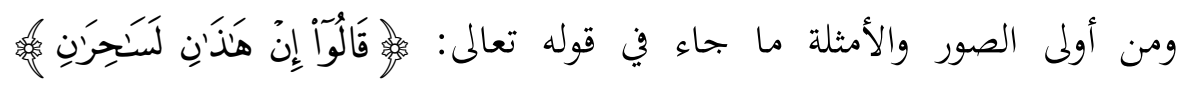

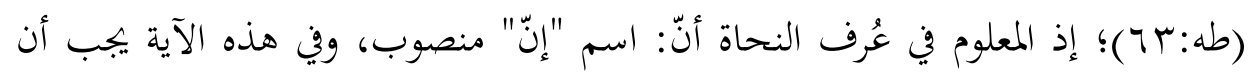

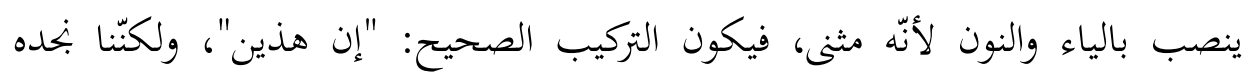

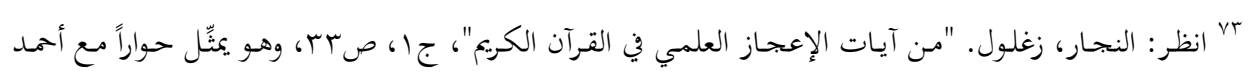

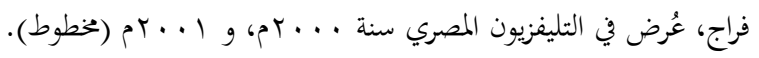


مرفوعاً بالألف والنون [إن هذان...]، والسرّ في ذلك هو معاني ودلالات الآية التي تدور

$$
\text { حيث دارت صيغ إعرابها. }
$$

قال ابن هشام في كتابه "شرح شذور الذهب في معرفة كلام العرب" مُعرباً الآية:

$$
\text { وقد أجيب عليها بأوجهه: }
$$

الأول- أن لغة بلحارث بن كعب، وخثعه، وزبيد، وكنانة وآخرين استعمالُ المثنى

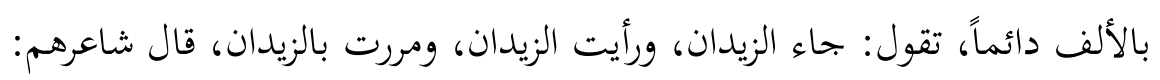

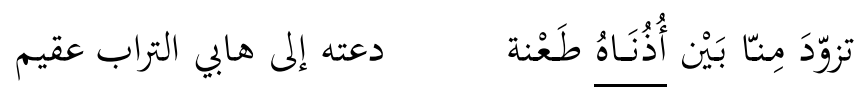

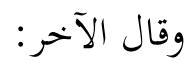

إن أباها وأبا أباها

فهذا مثال بحيء المنصوب بالألف، وذاك مثال بجيء المجرور بالألف.

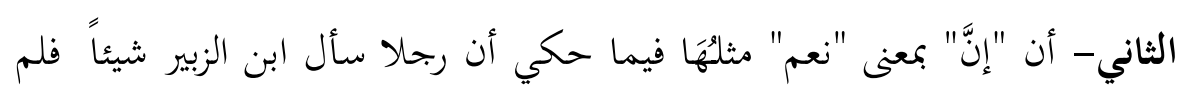
يعطه، فقال: لعن الله ناقة حملتي إليك، فقال: "إنَّ وراكِبَهَا"، أي نعم ولعن الله راكبها،

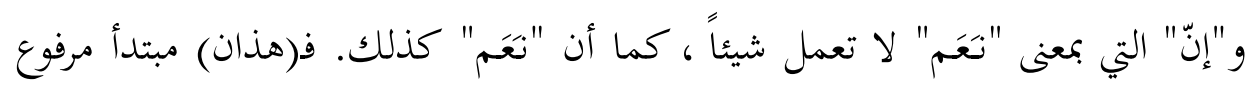
بالألف، و وساحران) خبر لمبتدأ محذوف، أي: لمما ساحران، والجملة خبر (هذان) ولا

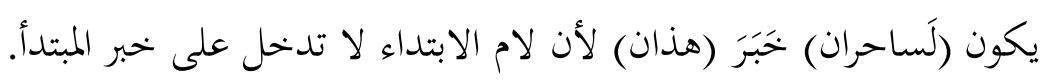
الثالث- أن الأصل "إنه هذان لمما ساحران"، فالهاء ضمير الشأن، وما بعدها

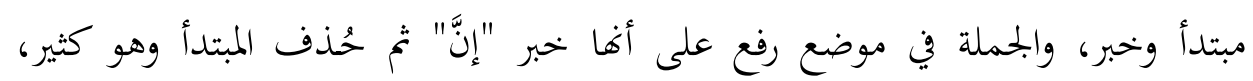

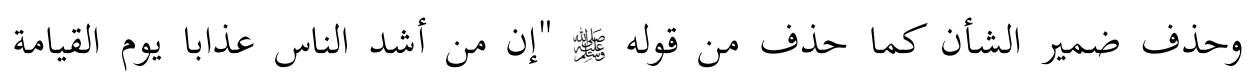
المصورون" ومن قول بعض العرب "إنَّ بك زيدٌ مأخوذ".

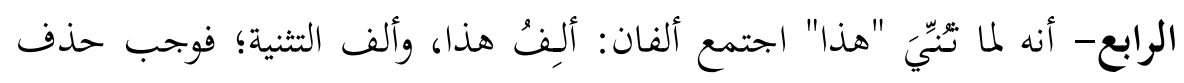
واحدة منهما لالتقاء الساكنين؛ فمن قـدَّر المحذوفة ألف "هذا" والباقية ألف التثنية قلبها

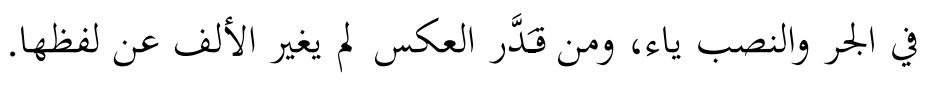




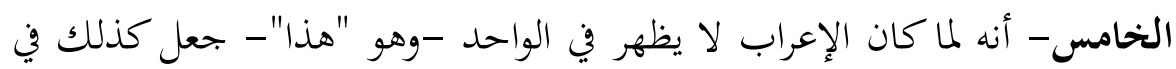

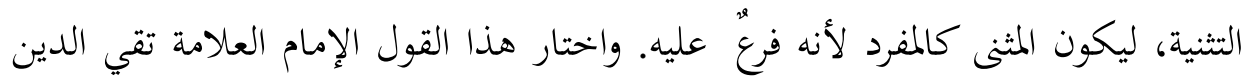

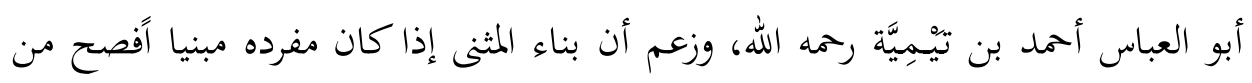

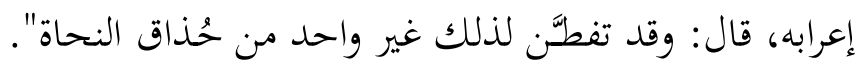

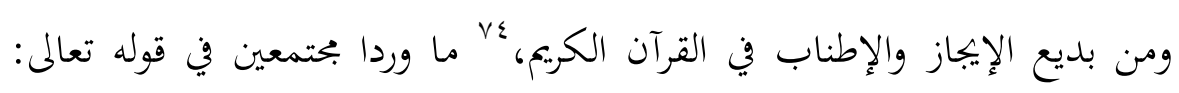
وَارِ

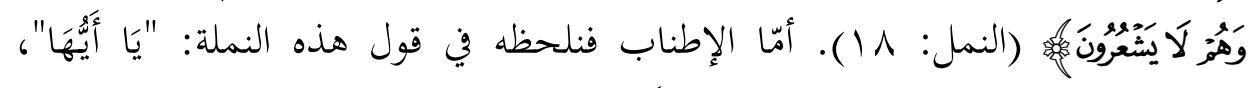

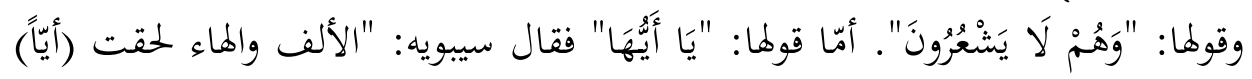

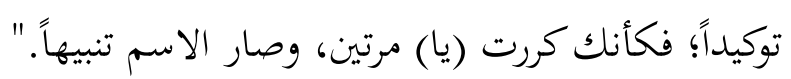

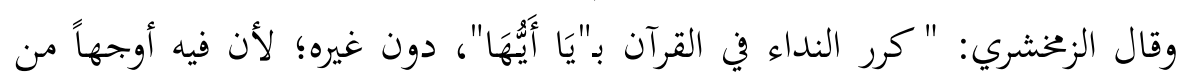

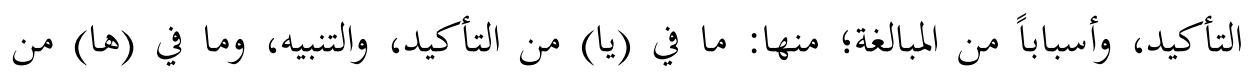

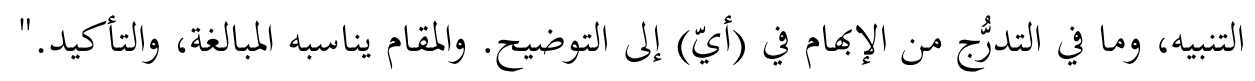

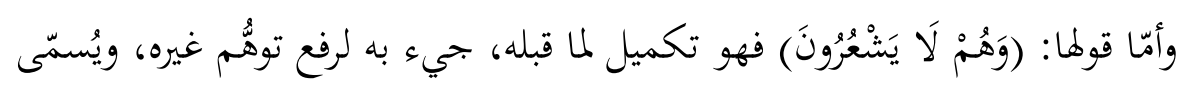

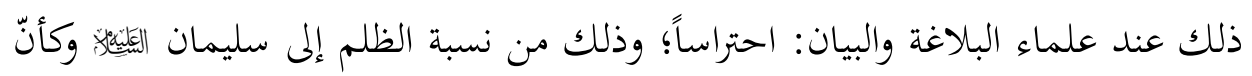

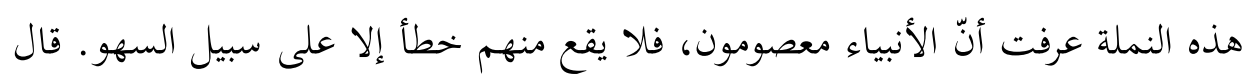

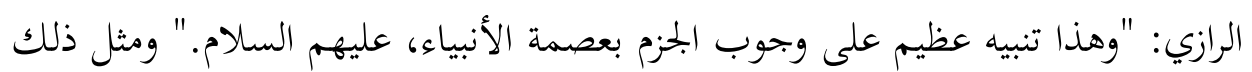

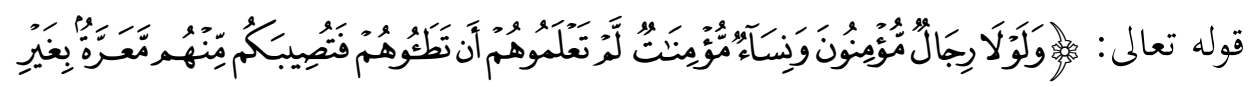

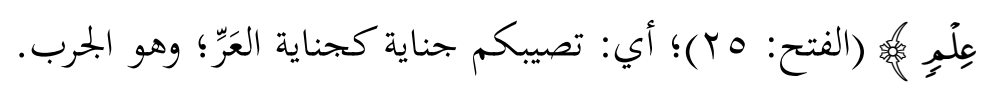

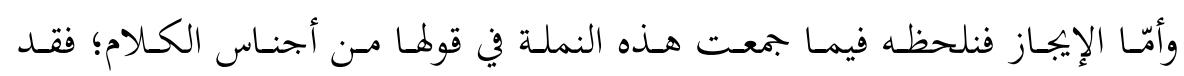

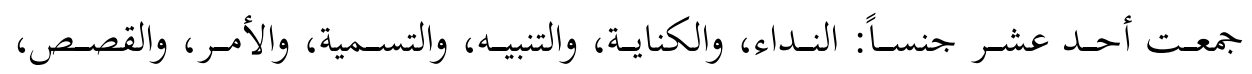

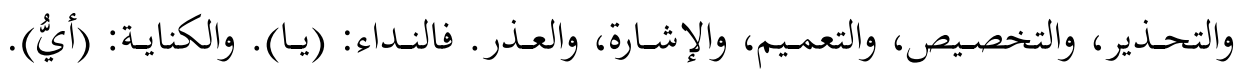

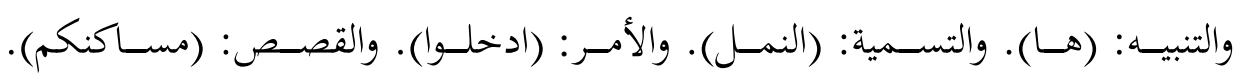

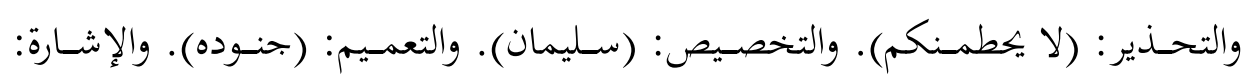

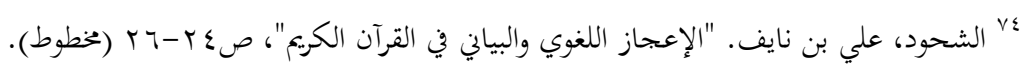


(هـم). والعذر: (لا يشعرون). فأدَّت هذه النملة بذلك خمسة حقوق: حقّ الله تعالى،

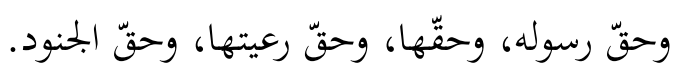

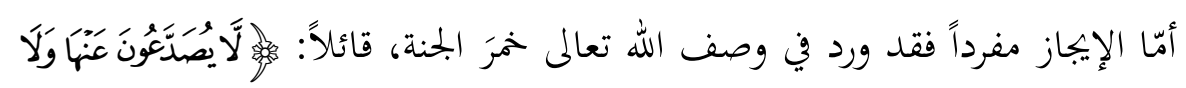

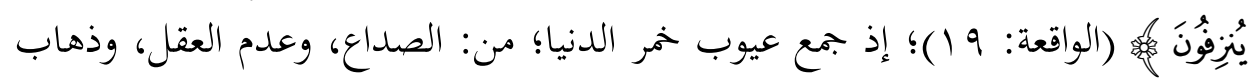

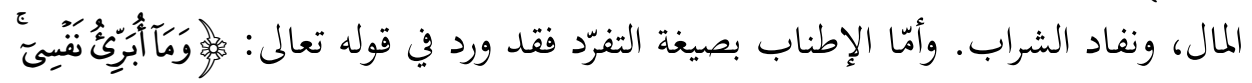

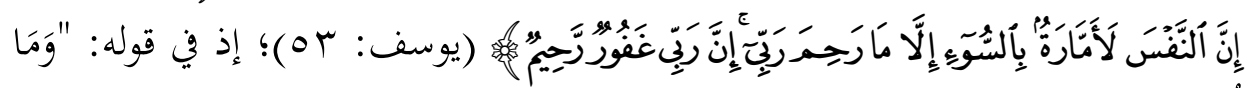

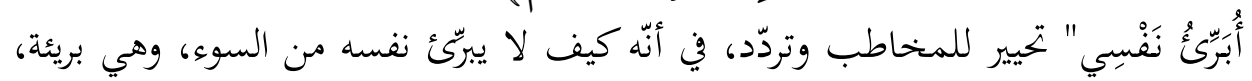

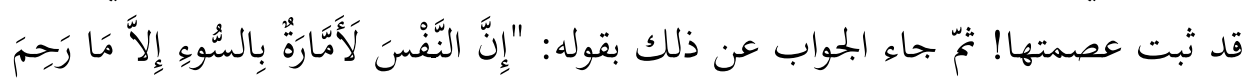

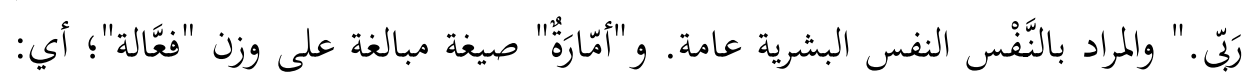

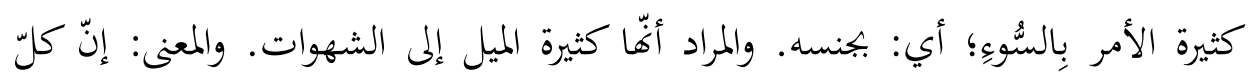

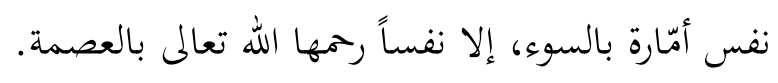

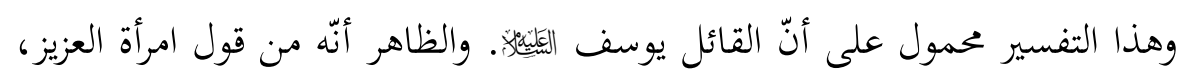
وأنّه اعتذار منها عمّا وقعت فيه مّّا يقع فيه البشر من الشهوات. والمعنى: وما أبرّئ

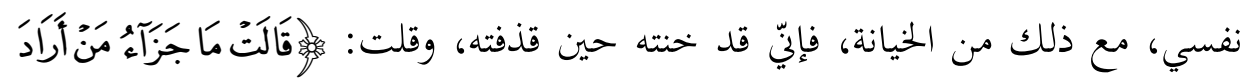

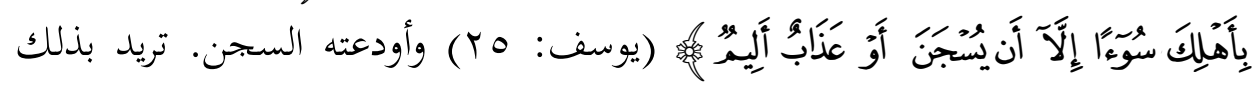

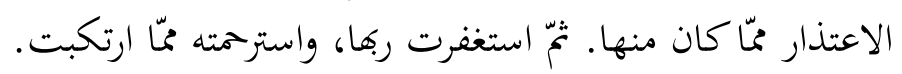

\section{سادساً: في أنّ الصلاة تُكُرَه أو تَبْطُل خلف إمام يلحن في القراءة}

اعتباراً لما رأينا، اتضح لنا بالدليل جلال فقه اللغة في الاجتهاد المقاصدي بوصفه مستلزمة من مستلزمات العمل بالمقاصد، وتتمظهر بلاغة البُعْد اللغوي بصورة أكثر جلاء

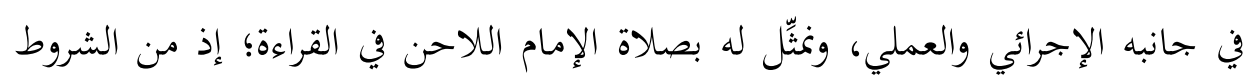

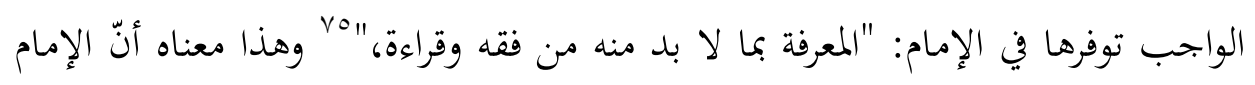

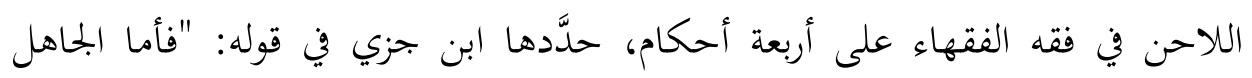

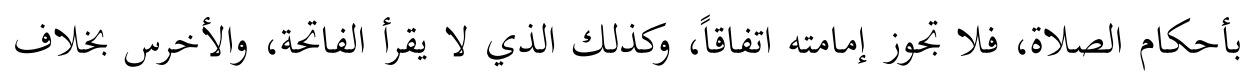


الألكن. أما اللحان فأربعة أقوال، يفرق في الثالث بين من يلحن في أم القرآن وغيرها،

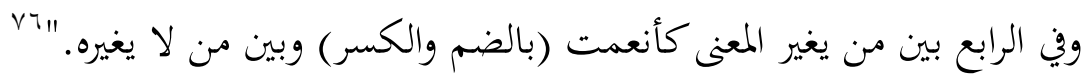

$$
\text { وفي ما يأتي بسط للأقوال الأربعة: }
$$

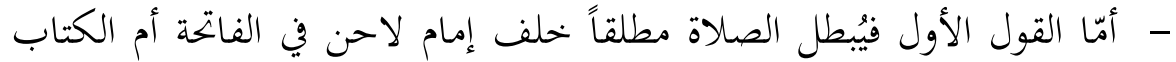

- - والقول الثاني يعتقد صحتها مطلقاً.

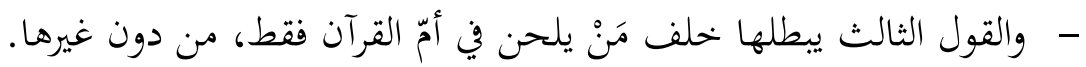

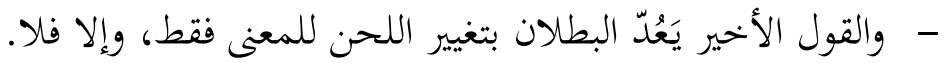

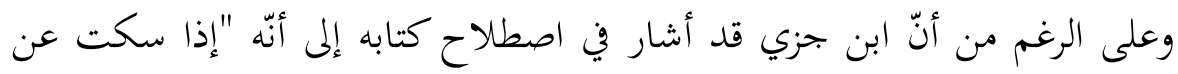

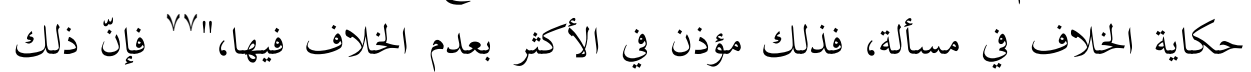

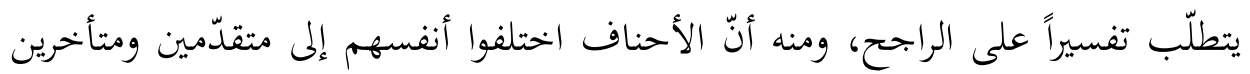

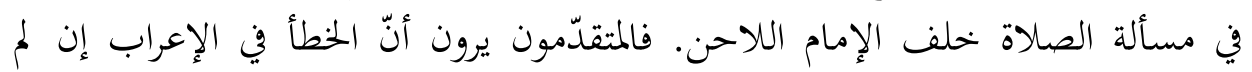

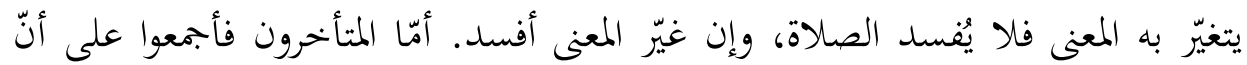

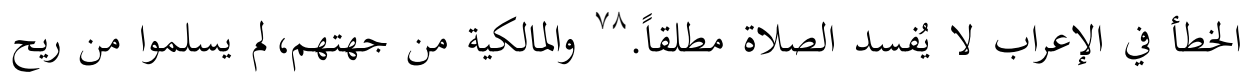

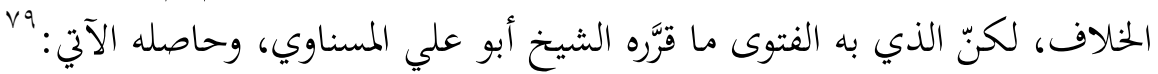

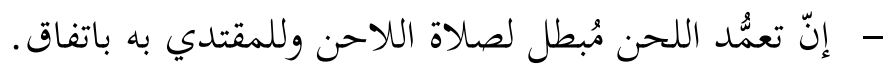

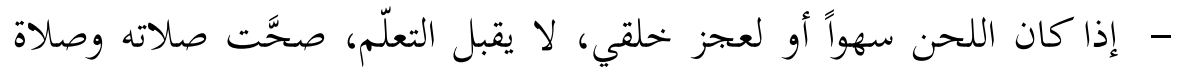
مَنْ خلفه باتفاق.

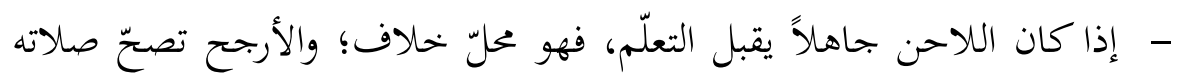
وصلاة المقتدي به.

أمّا الشافعية فقد قصروا بطلان الصلاة على تغيير المعنى. فاللاحن الذي لا يغيّر

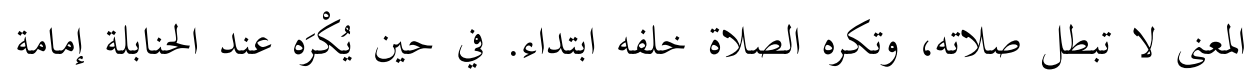

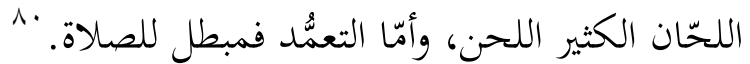

$$
\text { צrv }
$$

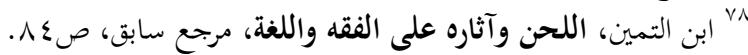

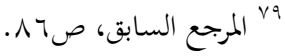

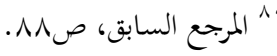




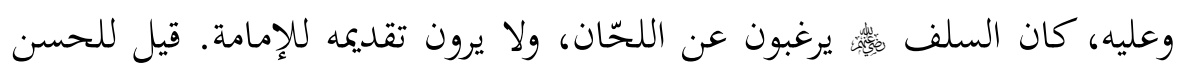

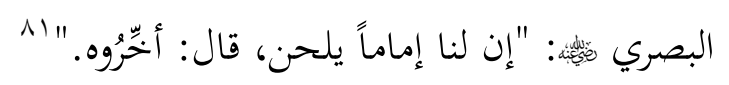

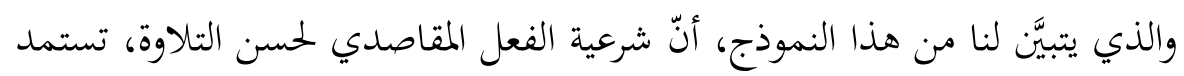

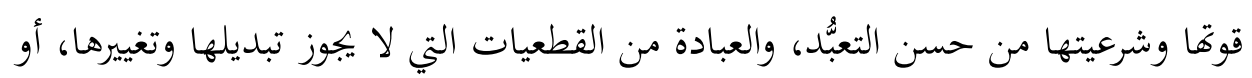

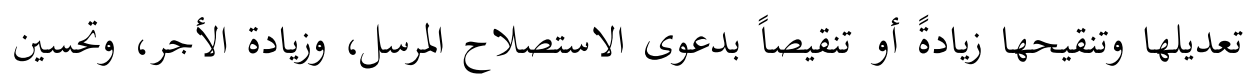

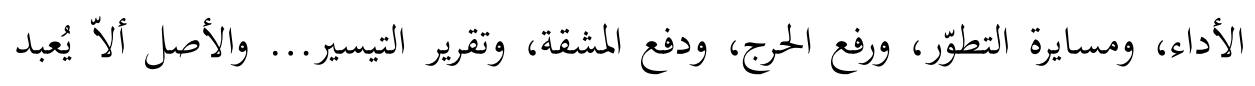

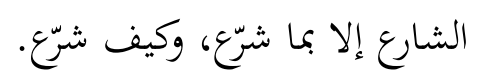

ولنا حقّ الحكم على إمام يقلب "الثاء" "سينا"، في لفظ "الغيث"؛ إذ يقرؤها

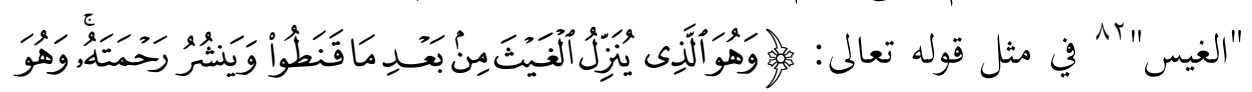

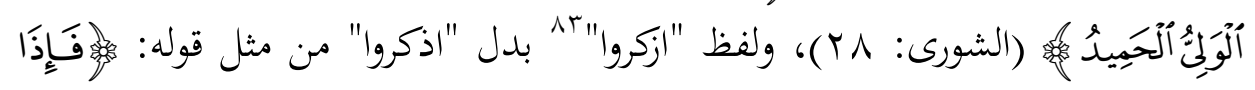

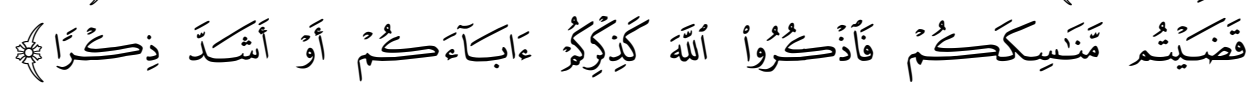

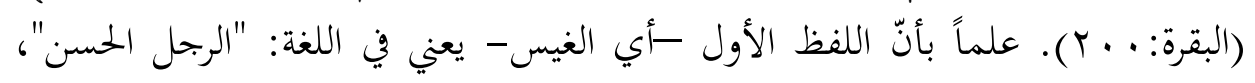
واللفظ الثاني -أي الزكر - يعني: "الملى"، وشتّان بين المعنيين واللفظين.

ومثل هذا اللحن يدخل ضمن صنوف اللحن الجلية التي يأثم صاحبها. وهو كما قال ابن الجزري خلل يطرأ على الألفاظ فيُخلّ بعرف القراءة؛ سواء أخلّ بالمعنى أم لا. ومن صوره:

- - الذي يُخلّ بعرف القراءة والمعنى؛ كتغيّر حركة بحركة، نخو ضم التاء أو كسرها في

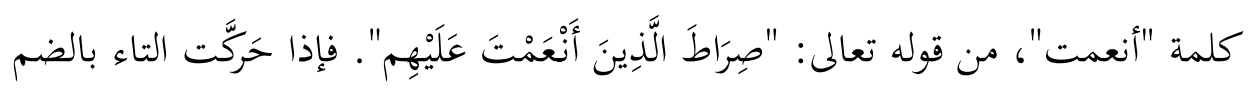
بدل الفتح فكأنّك جعلت القارئ هو المنعم الثاني.

- - الذي يُخلّ بالعُرف من دون المعنى، نحو رفع الهاء أو نصبها، من قوله تعالى:

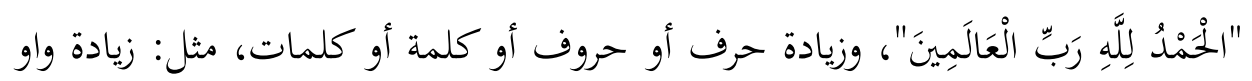

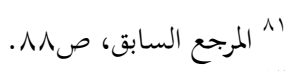

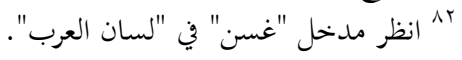

$$
\begin{aligned}
& \text { rro انظر مدخل "زكر" في "لسان العرب". في "لعان العرب". }
\end{aligned}
$$


قبل "إن للمتقين مفازا"، وتبديل حرف بآخر، حين تجد بعضهم يقلب السين إلى صاد،

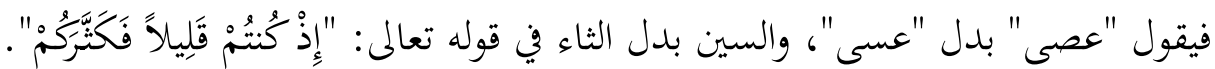
والأمة كما أفّّا "متعبدة بفهم معاني القرآن، وإقامة حدوده، مُتَعَبِدُون أيضاً بتصحيح ألفاظه، وإقامة حروفه على الصفة، المتلقاة عن أئمة القراءة، المتصلة بالحضرة النبوية

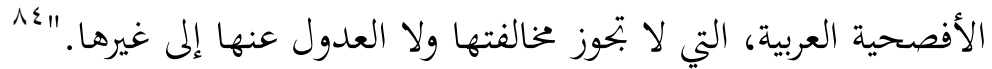

خاتمة:

لقد حاول البحث -ومن خلال محاوره- أن يثبت بأنّ المعرفة باللغة العربية كانت وستظلّ- الواجبَ الطبيعي الذي يكفل فهم النص القرآي فهماً يتوافق ومقاصده الشرعية التي جاءت لتضمن للبشر حقهم؛ في: النسل، والعقل، والنفس، والمال، والدين، في إطار الكلّيات الخمس المعروفة. لذلك كان التكفّل الرباني بحفظ القرآن الكريم مصاغاً في ضوء

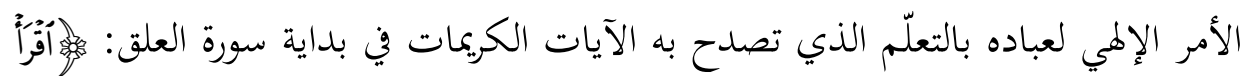

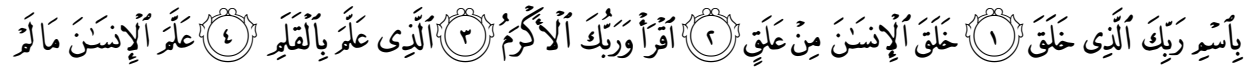

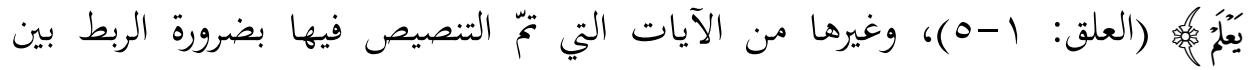
الشريعة الإسلامية واللغة العربية، من باب أنّ تمام معرفة القرآن لا تحصل إلا بتمام معرفة اللغة التي نزل بها.

فلا شكّ -إذن- في أنّ معرفة الشريعة الإسلامية متصلة بعلم اللغة العربية، وهذا الاتصال حاضر في فكر أمّة القرآن على الدوام، بما نصّ عليه كبار فقهاء الدين وعلماء المِلّة؛ على غرار ما ألحنا إليه سلفاً، كما نزكّيه اللحظة بما أورده الإمام الشافعي -رحمه الله تعالى - الذي قال: "فعلى كل مسلم أن يتعلم من لسان العرب ما بلغه جهده حتى ترديه

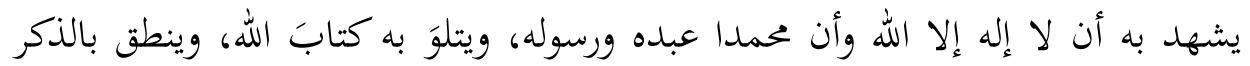

§^ ابن الجزري، محمد. النشر في القراءات العشر، تحقيق: علي محمد الضباع، بيروت: دار الكتب العلمية، د.ت، 
فيما افترض عليه من التكبير وأُمرَ به من التسبيح والتشهد وغير ذلك. وما ازداد من العلم باللسان الذي جعله الله لسان من ختم به نبوته وأنزل به آخر كتبه كان خيرا. "1ه وبذا، يكقّ لنا التأكيد ختاماً؛ على أنّ اللغة سُّم ومرقاة إلى جميع العلوم والمعارف، ومَنْ لا يعلم اللغة العربية أو ينتقص منها، فلا سبيل له إلى تحصيل العلوم والمعارف؛ لأنّ

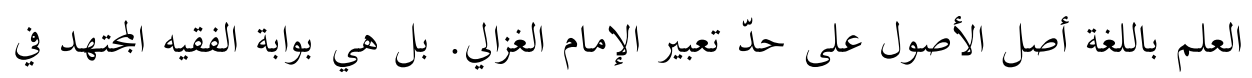

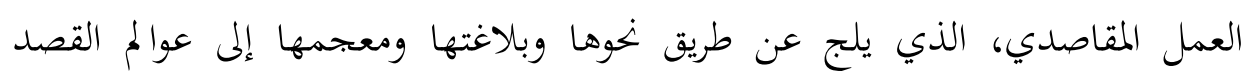
الرباني؛ لتبيُّن الدليل من المدلول، ومَنْ يقوم على النص مُّن يفتقر إليه. 